\title{
Black Sea "Lake" reservoir age evolution since the Last Glacial - Hydrologic and climatic implications
}

\author{
Guillaume Soulet a,b,*, Guillemette Ménot ${ }^{a}$, Vincent Garreta ${ }^{a}$, Frauke Rostek ${ }^{\text {a }}$, Sébastien Zaragosi ${ }^{\mathrm{c}}$, \\ Gilles Lericolais ${ }^{\mathrm{b}}$, Edouard Bard ${ }^{\mathrm{a}}$ \\ a CEREGE, UMR6635, CNRS-IRD, Université Paul Cézanne Aix-Marseille, Collège de France, Europôle de l'Arbois, BP 80, 13545 Aix-en-Provence Cedex 04, France \\ b IFREMER, Centre de Brest, Géosciences Marines BP70, 29280 Plouzané Cedex, France \\ ' Université Bordeaux I, UMR5805 EPOC, Avenue des Facultés, 33405 Talence, France
}

\section{A R T I C L E I N F O}

\section{Article history:}

Received 9 November 2010

Received in revised form 31 May 2011

Accepted 1 June 2011

Available online 24 June 2011

Editor: P. DeMenocal

\section{Keywords:}

Black Sea

reservoir age

radiocarbon

Last Glacial

Last Deglaciation

paleoclimate

\begin{abstract}
A B S T R A C T
Chronologies of sediments that document the last glacial history of the Black Sea "Lake" are hampered by issues relating to reservoir age. Regulated by basin hydrology, reservoir ages represent a tool that could potentially be used to better understand the response of Black Sea "Lake" hydrology to climate change. Therefore, deciphering reservoir age evolution is crucial both for better constraining the basin chronological framework and for providing new insights into our understanding of Black Sea "Lake" hydrology.

By tuning a meaningful new high-resolution geochemical dataset (obtained from core MD04-2790) to a climate reference record, here, we propose a reliable chronology spanning the last $32 \mathrm{kyr}$ BP. The chronology is compared to a large AMS radiocarbon dataset $(n=51)$. Pairs of calendar and radiocarbon ages allowed us to compute reservoir ages, and to, then, reconstruct a high-resolution quantitative reservoir age record for the last glacial history of the Black Sea "Lake".

The main factor controlling reservoir ages in lakes is the Hard Water Effect (HWE), which is regulated by basin hydrology. Therefore, changes in the reconstructed reservoir age record have been qualitatively interpreted in terms of the hydrologic responses of the Black Sea "Lake" to climate change. Our results allowed us to determine periods of complete isolation or outflow for the Black Sea "Lake". During Heinrich Event 2 (HE2) and during the Last Glacial Maximum (LGM) the basin was strictly isolated, whereas prior to HE2 and during HE1 it outflowed into the Marmara Sea. Following the onset of the Bølling-Allerød, factors other than the HWE are thought to have influenced the reservoir age, preventing conclusive interpretations. We also determined an undocumented, to date, phase of Black Sea "Lake" stratification during the full glacial (HE2 and LGM). Our results indicate that reservoir age is a powerful tool for investigating and better understanding past hydrologic changes in lakes and inland seas.
\end{abstract}

(c) 2011 Elsevier B.V. All rights reserved.

\section{Introduction}

During the last global lowstand and for much of deglacial ocean level rise, the Black Sea was disconnected from the global ocean and evolved as a giant lake with its water level controlled by regional climate (e.g. Ross et al., 1970; Schrader, 1979; Stoffers et al., 1978). The last reconnection of the Black Sea "Lake" to the global ocean occurred at 9000 yr BP (Ryan, 2007; Soulet et al., 2011). The previous prevalent hypothesis of a smooth reconnection (e.g. Fedorov, 1971; Ross et al., 1970) was challenged when Ryan et al. (1997) proposed that Mediterranean waters breached the Bosphorus sill leading to a catastrophic refilling of the Black Sea basin. Attendant flooding of the

\footnotetext{
* Corresponding author at: CEREGE, UMR6635, CNRS-IRD, Université Paul Cézanne Aix-Marseille, Collège de France, Europôle de l'Arbois, BP 80, 13545 Aix-en-Provence Cedex 04, France.

E-mail address: soulet@cerege.fr (G. Soulet).
}

vast emerged continental shelf would have led to a massive migration of Neolithic farmers, imprinting collective memory through culturallywidespread deluge myths (Ryan and Pitman, 1998). In a decade, the "Flood hypothesis", as well as its possible cultural consequences, has been a matter of debate (e.g. Aksu et al., 2002a; Hiscott et al., 2007; Ryan, 2007; Ryan et al., 2003; Yanko-Hombach et al., 2007).

The lack of reliable Black Sea "Lake" level markers (Giosan et al., 2006; Pirazzoli, 1991), the scarcity of radiocarbon ages on in situ materials, and the difficulty in constraining basin reservoir ages (Giosan, 2007; Kwiecien et al., 2008; Ryan, 2007) mainly explain uncertainties surrounding the last reconnection. Since Black Sea "Lake" level is directly linked to the basin water budget, disentangling the last reconnection mystery also relies on a better understanding of the response of Black Sea "Lake" hydrology to glacial and deglacial climate changes. Recently, several high-resolution geochemical studies (Bahr et al., 2005, 2006, 2008; Kwiecien et al., 2008, 2009; Major et al., 2002, 2006) have considerably increased our knowledge 
regarding Black Sea "Lake" hydrologic responses to climate change. However, meaningful interpretations in terms of Black Sea "Lake" paleohydrology must rely upon robust chronologies, a limiting factor for most studies, due to poorly-constrained basin reservoir ages.

The reservoir age of a water body is the difference between the radiocarbon ages of the water body and the contemporary atmosphere (Arnold and Anderson, 1957; Bard, 1988; Craig, 1957; Stuiver and Polach, 1977; Stuiver et al., 1986; Suess and Revelle, 1957). Reservoir age changes throughout time are directly linked to changes in reservoir parameters (e.g. water input and output, exchange with the atmosphere, the size of the carbon pool, etc.) and in atmospheric $\Delta^{14} \mathrm{C}$. As a consequence, reservoir ages represent a powerful tool for reconstructing the response of the reservoir to climate change (e.g. Bard, 1988; Bard et al., 1994; Bondevik et al., 2006; Mangerud, 1972; Siani et al., 2001; Stuiver et al., 1986).

Closed basins (lakes, inland seas) are extremely sensitive to climate change. As a result, lake reservoir ages vary markedly (e.g. Stein et al., 2004; Zhou et al., 2009). The strong sensitivity of the Black Sea "Lake" to climate change is now well established (Bahr et al., 2005, 2006, 2008; Kwiecien et al., 2008, 2009; Major et al., 2002, 2006). First attempts to decipher Black Sea "Lake" reservoir ages were performed using rough comparisons between Black Sea "Lake" geochemical records and Greenland ice core records (Kwiecien et al., 2008; Ryan, 2007). Although these pioneering results provided important insight into our understanding of Black Sea "Lake" reservoir age variability, they only represented rough estimations. To date, a single reservoir age has been quantitatively reported $\left(1450 \pm 400{ }^{14} \mathrm{C}\right.$ yr; Kwiecien et al., 2008). Providing a quantitative reservoir age record throughout last glacial Black Sea "Lake" history is critical for properly calibrating radiocarbon ages obtained from biota grown within the basin and for better constraining the hydrologic response of this former lake to climate change.

Based upon new high-resolution geochemical records, obtained from a sedimentary sequence from the Black Sea tuned to ${ }^{230} \mathrm{Th}$-dated Hulu Cave climate records (Wang et al., 2001), here, we propose a calendar chronology for glacial to deglacial sediment of the Black Sea "Lake". The obtained calendar chronology is then compared to a previously published dataset of AMS radiocarbon ages (Bahr et al., 2005; Kwiecien et al., 2008; Major et al., 2002), as well as to numerous original dates. For this study, we developed a statistical method for computing reservoir ages, and provide a quantitative high-resolution reservoir age record of the Black Sea "Lake" spanning the last $32 \mathrm{yr}$ BP. We also qualitatively interpret large and abrupt reservoir age changes in terms of the hydrologic responses of the Black Sea "Lake" to climate change.

\section{Materials and methods}

\subsection{Material}

Piston core MD04-2790 was recovered in the upper slope of the NW Black Sea ( $44^{\circ} 12.8^{\prime} \mathrm{N}, 30^{\circ} 59.6^{\prime} \mathrm{E} ; 352 \mathrm{~m}$ water depth), in the direct axis of the Danube River (Fig. 1) during the ASSEMBLAGE 1 cruise, aboard Marion Dufresne. From the top to a depth of $1.24 \mathrm{~m}$, the core revealed the typical marine stratigraphic Units I and II (Ross and Degens, 1974). The lowermost limnic unit, Unit III (Ross and Degens, 1974), was found at a depth of $1.24 \mathrm{~m}$ to the core base. The base of Unit III was not reached. A careful inspection of MD04-2790 core sediments revealed neither a turbiditic sequence nor a visible unconformity.

\subsection{Methods}

2.2.1. High-resolution geochemical records (XRF profiles, $\mathrm{CaCO}_{3}$, and TOC)

The bulk intensity of numerous major elements was determined using an Avaatech XRF-core scanner (Jansen et al., 1998). Measurements were performed on every millimeter on the split core at Ifremer (Brest, France) by setting the voltage to $10 \mathrm{kV}$ and the intensity to $1000 \mathrm{~mA}$. The acquisition time was $20 \mathrm{~s}$. Here, we present XRF profiles useful to build the chronology of MD04-2790 sedimentary sequence: the Ca-intensity (calcium) and the Ti/Ca-ratio (titanium vs. calcium ratio) profiles.

The carbonate content $\left(\mathrm{CaCO}_{3}\right)$ and the Total Organic Carbon (TOC) content were measured at CEREGE (Aix en Provence, France) with a FISONS NA 1500 elemental analyzer, as described in Pailler and Bard (2002). Sediment samples were freeze-dried, crushed, and homogenized in an agate ball mill. Both the Total Carbon (TC) and the TOC contents of each sample were determined in two separate

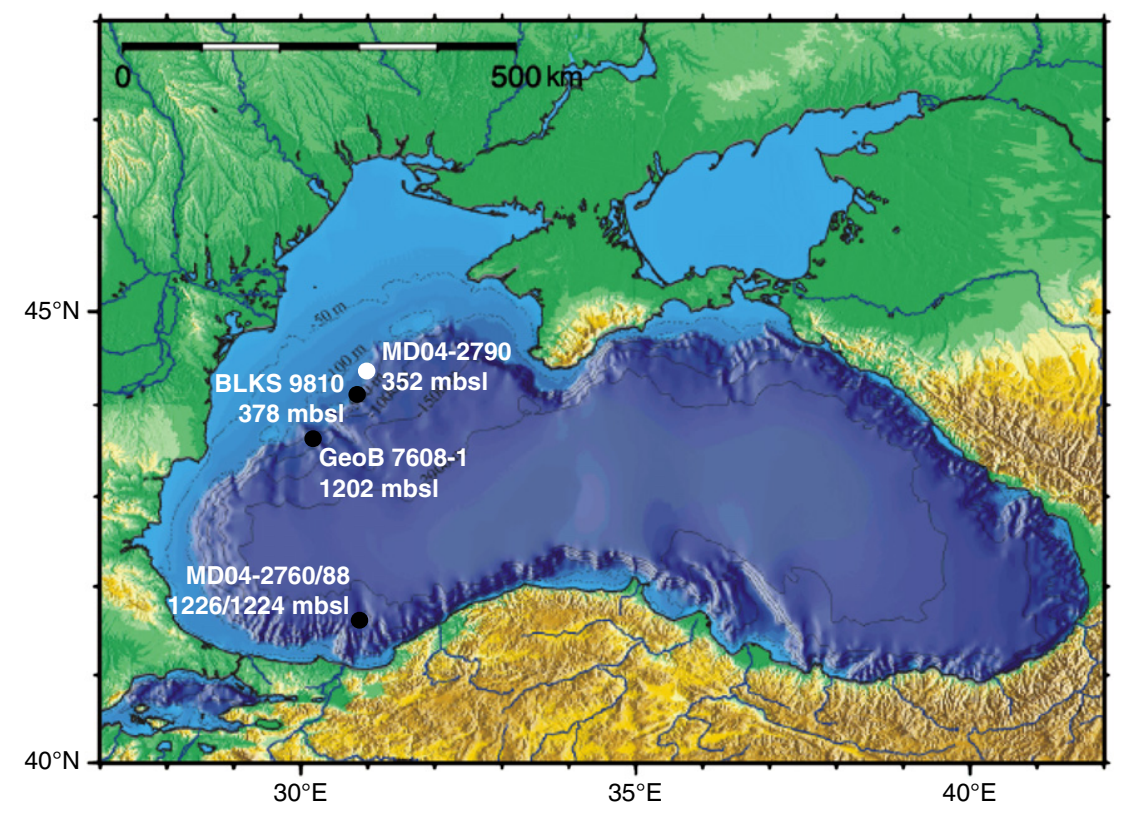

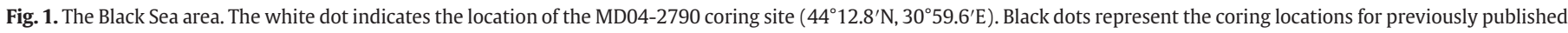

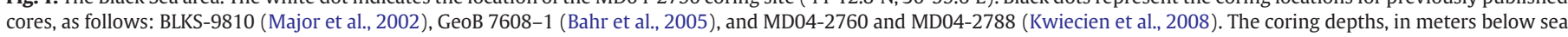
level (mbsl), are indicated below the coring sites. 
analyses. We measured TOC after an acid removal of the carbonate fraction. Each TOC measurement was duplicated. In order to calculate the dry weight percentages of calcium carbonate, the following equation was applied: $\mathrm{CaCO}_{3}=(\mathrm{TC}-\mathrm{TOC}) \times 8.33$. Two major authigenically-precipitated $\mathrm{CaCO}_{3}$ peaks (Bahr et al., 2005; Major et al., 2002) occurred, approximately, within the first $3 \mathrm{~m}$ of the core and quickly increased in total $\mathrm{CaCO}_{3}$ content from $~ 15 \%$ to $45 \%$, then to $65 \%$, thus diluting TOC. As a result, each measured TOC value was corrected for $\mathrm{CaCO}_{3}$ dilution $\left(\mathrm{TOC}_{\text {corrected }}=100 \times\left(\mathrm{TOC}_{\text {measured }} /\left(100-\mathrm{CaCO}_{3}\right)\right)\right.$, in \%). Three hundred samples were measured, with one sample taken every 5 or $10 \mathrm{~cm}$.

The obtained high-resolution geochemical records (Fig. 2) were very similar to those previously published, as follows: Bahr et al. $(2005,2006)$ and Kwiecien et al. $(2008,2009)$ for XRF-Ca and XRF-Ti/ $\mathrm{Ca}$; Kwiecien et al. (2009) and Major et al. (2002) for $\mathrm{CaCO}_{3}$; Bahr et al. (2008) for TOC. Therefore, in the following, we do not discuss our high-resolution geochemical records and instead refer the reader to discussions contained in the studies cited above.

\subsubsection{Lake Surface Temperatures (LST)}

Lake Surface Temperatures (LST) were calculated using the GDGT thermometer $\mathrm{TEX}_{86}$ and the calibration equation provided by Schouten et al. (2002). Our analytical methods were assessed in the frame of an international comparison. Results from our laboratory were found to compare favorably with data from other laboratories (Schouten et al., 2009). Details regarding the analytical methods and the calibration comparisons will be provided elsewhere (Ménot et al., in preparation).

\subsubsection{Calendar age model reconstruction}

The calendar chronology for core MD04-2790 was reconstructed by tuning our high-resolution geochemical dataset (Fig. 3) to the Hulu Cave $\delta^{18} \mathrm{O}$ record (Wang et al., 2001). The stratigraphic approach is similar to that performed on marine sequences (Bard et al., 2004; Hughen et al., 2006). Tuning relies upon an assumption of synchronous climate changes throughout the Northern Hemisphere. Climate synchroneity is consistent with studies which have identified abrupt

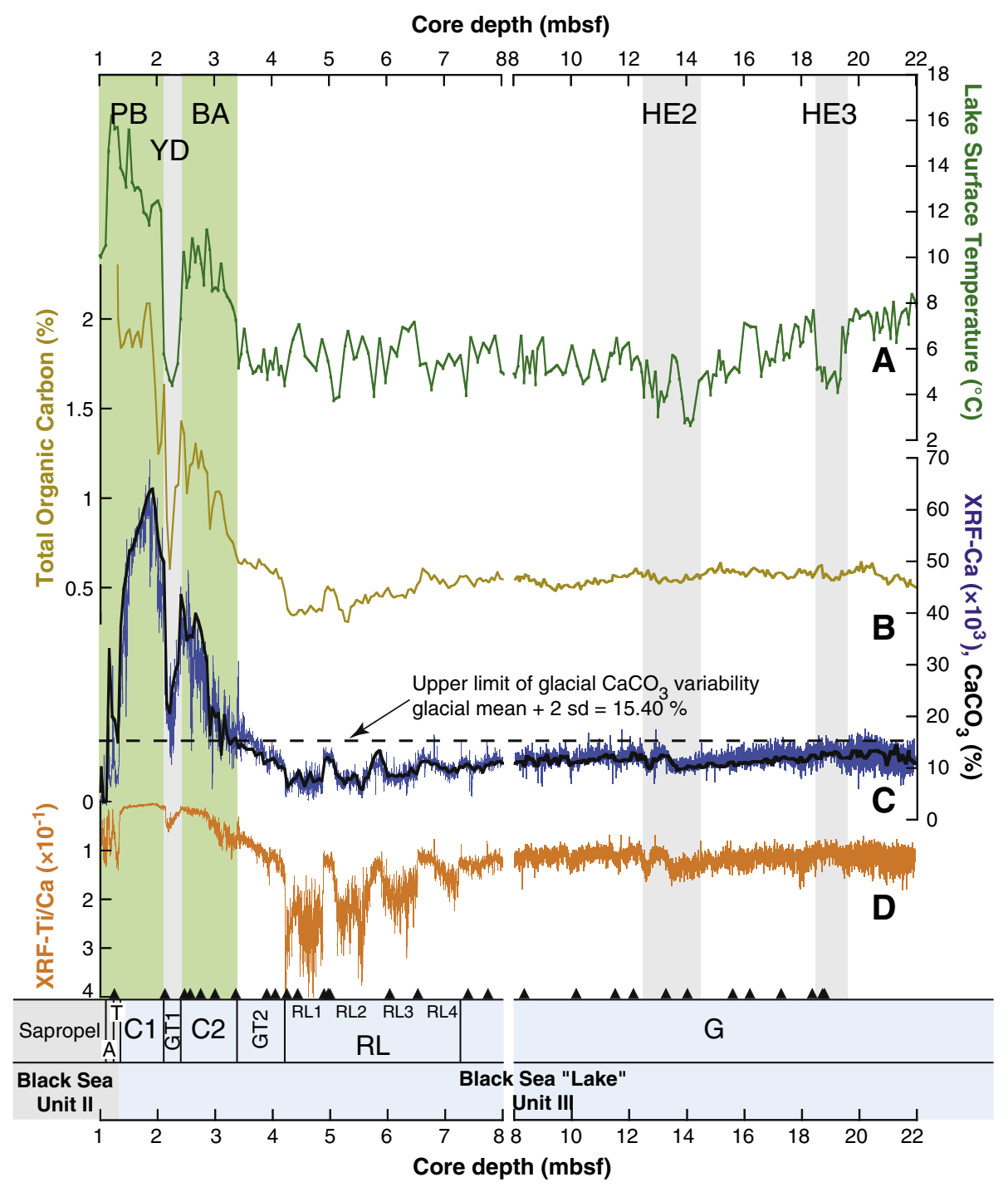

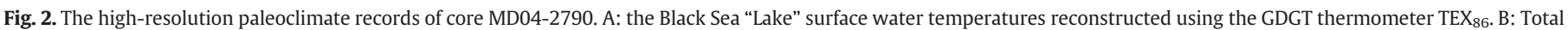

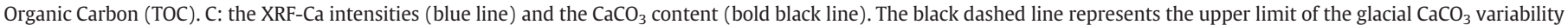

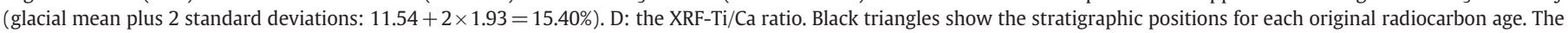

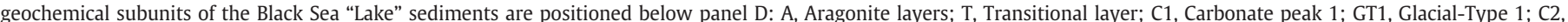

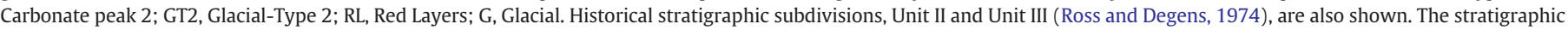

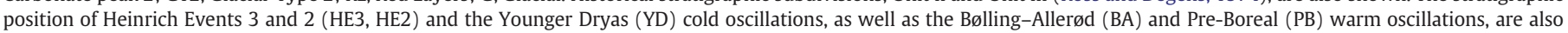
indicated. Note that, for optical reasons, the depth scale between 1 and $8 \mathrm{~m}$ is different from the depth scale between 8 and $22 \mathrm{~m}$. 


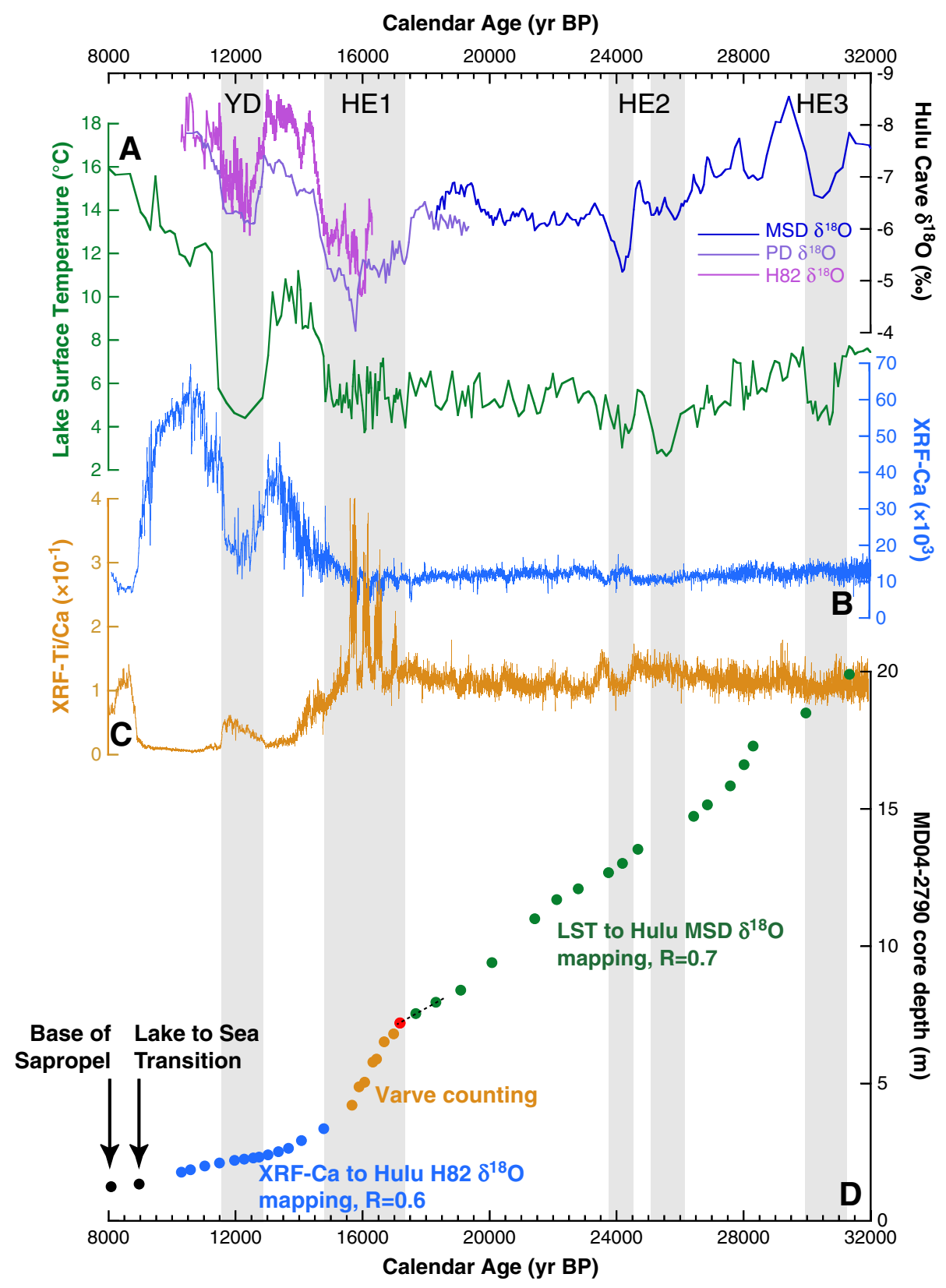

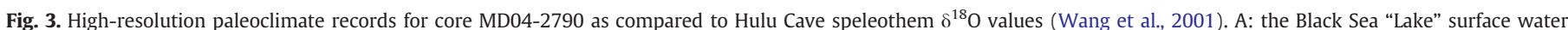

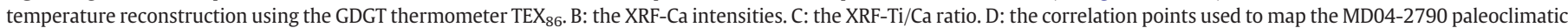

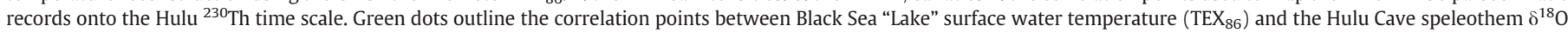

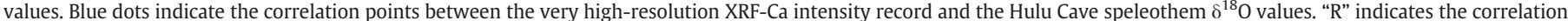

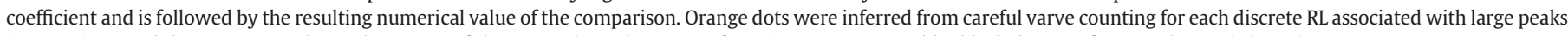
in XRF-Ti/Ca. Red dot represents the anchor-point of the varve chronology. Data from items represented by black dots are from Soulet et al. (2011).

climate shifts in proxies measured within the same archive yet related to different parts of Earth's environmental system. Such studies have found no significant stratigraphic lag (i.e. no temporal lag) (Fleitmann et al., 2009; Hughen et al., 2004; Ruth et al., 2007; Severinghaus and Brook, 1999; Severinghaus et al., 1998; Steffensen et al., 2008; Wolff et al., 2010).

From the Bølling-Allerød to the Pre-Boreal we assumed that highresolution XRF-Ca variability was linked to variability in productivity within Black Sea "Lake" surface water, which is, itself, driven by northhemispheric climate variability. Indeed, Bølling-Allerød and PreBoreal warm oscillations are geochemically characterized by prominent maxima in XRF-Ca intensities, $\mathrm{CaCO}_{3}$ content, and $\mathrm{TOC}$ ( $\mathrm{C} 2$ and $\mathrm{C} 1$ in Fig. 2). Between these maxima, a glacial-type interval (GT1 in Fig. 2) is geochemically characterized by near glacial values, representing the Younger Dryas cold event (Bahr et al., 2005, 2008; Kwiecien et al., 2008; Major et al., 2002; Fig. 2). $\mathrm{CaCO}_{3}$ maxima (C2 and C1) are mainly composed of authigenically-precipitated calcite (Bahr et al., 2005; Major et al., 2002). Precipitation of authigenic calcite within lakes results from the photosynthetic utilization of $\mathrm{CO}_{2}$ and resultant calcium carbonate supersaturation in the water column during the growing season (Leng and Marshall, 2004). High TOC accompanying strong increases in authigenic calcite strengthens the hypothesis that both $\mathrm{CaCO}_{3}$ maxima (Fig. 2) were deposited under high productivity conditions that prevailed during the Bølling-Allerød and the PreBoreal warm oscillations. During the Younger Dryas (GT1 interval, Fig. 2), carbonates are mainly detrital (Bahr et al., 2005; Major et al., 
2002). However, $\mathrm{TOC}$ as well as $\mathrm{CaCO}_{3}$ values, even if lower compared to values occurring within the $\mathrm{C} 2$ and $\mathrm{C} 1$ intervals (Fig. 2), exceeded glacial values (Fig. 2). The Younger Dryas cooling was likely a winter phenomenon with no substantial summer change except for the length of the growing season (for a review, see Denton et al., 2005). As a result, the observed XRF-Ca, $\mathrm{CaCO}_{3}$, and TOC drops likely occurred due to a shorter growing season in Black Sea "Lake" surface waters. This suggests that during the Younger Dryas, productivity, even if reduced, was not negligible. Therefore, variability in our high-resolution XRF-Ca profile represents a suitable record for productivity variability within late glacial Black Sea "Lake" surface waters. Of interest is that a similar variability has been observed in high-resolution records on the northhemispheric scale (Ruth et al., 2007) within the following: Ice Core $\delta^{18} \mathrm{O}$ (e.g. NGRIP members, 2004), Chinese speleothems $\delta^{18} \mathrm{O}$ (e.g. Wang et al., 2001), and pollen records from Merfelder Maar (Germany) (Litt et al., 2001). These similar findings support our assumption that Black Sea "Lake" productivity variability was primarily driven by north-hemispheric climate variability. Therefore, between 14.8 and $10 \mathrm{kyr}$ BP, variability in the XRF-Ca record (Fig. 3) was confidently tuned to the $\delta^{18} \mathrm{O}$ variability of the ${ }^{230} \mathrm{Th}$-dated Hulu Cave records (Fig. 3) $(\mathrm{R}=0.6)$. Note that the Bølling-Allerød onset is defined as the first sample that displays a $\mathrm{CaCO}_{3}$ content that exceeds glacial $\mathrm{CaCO}_{3}$ variability (the glacial $\mathrm{CaCO}_{3}$ mean + two standard deviations). The defined core depth corresponds to a sudden increase in Lake Surface Temperature inferred from $\mathrm{TEX}_{86}$ (Fig. 2). A good correspondence between the independently defined tie points and concomitant changes in Lake Surface Temperature (LST) strengthened the robustness of the approach (Fig. 3).

During the glacial, due to extremely reduced productivity, as suggested by the low $\mathrm{CaCO}_{3}$ and TOC contents (Bahr et al., 2008; Kwiecien et al., 2009; Major et al., 2002; Fig. 2) and the detrital origin of carbonates (Bahr et al., 2005; Major et al., 2002), the XRF-Ca profile did not represent a suitable record for climate variability and did not provide any tie points. Fortunately, between 32 and $17.7 \mathrm{kyr}$ BP, the GDGT thermometer TEX $_{86}$ (Figs. 2 and 3) displayed northern hemispheric glacial climate variability. In particular, the strong LST troughs associated with Heinrich Events 3 and 2 cold spells (HE3 and HE2) were well expressed. Therefore, from 32 to $17.7 \mathrm{kyr}$ BP the LST variability was tuned to the $\delta^{18} \mathrm{O}$ variability of the ${ }^{230} \mathrm{Th}$-dated Hulu Cave records (Fig. 3) $(R=0.7)$. The reader should note that our tuning was derived from basic utilization of the LST obtained from TEX 86 measurements. A more in-depth discussion will be presented elsewhere (Ménot et al., in preparation).
Specific approaches were applied to the Red Layer (RL) interval and to the lacustrine to marine transition. MD04-2790 sediments display four discrete RLs that are easily recognizable by four strong "discrete" peaks in the XRF-Ti/Ca (Fig. 2), in agreement with previous work (Bahr et al., 2005, 2006; Kwiecien et al., 2009; Major et al., 2002, 2006). Each RL interval (Fig. 2) consists of an alternation of greenish-gray and red laminations that correspond to X-ray bright and dark laminations, respectively (Fig. 4). Observations of sediment thin sections (Fig. 4) indicate that each red lamination is characterized by high amounts of scattered silts and sands (mainly quartz) embedded in a reddish clayey matrix, suggesting that silts and sands represent Ice-Rafted Detritus (IRD). Dispersal of the outsized grains throughout the muds clearly indicates that the red laminations are not the result of turbiditic processes. Interestingly, this facies is strongly similar to the laminated facies described within the Armorican margin (Eynaud et al., 2007; Zaragosi et al., 2001). These features have been interpreted as possibly representing the springtime expulsion of anchor-ice (i.e. ice attached to the bed of rivers and including bed materials) by deglacial "Fleuve Manche" meltwater discharges (Toucanne et al., 2009). By analogy, each red clayish with IRD (X-ray dark) lamination likely represents spring meltwater discharge from NW Black Sea rivers, whereas each greenish-gray clayish (X-ray bright) lamination should represent "normal" sedimentation during the period spanning summer to winter. We tested this hypothesis by visually counting X-ray dark laminations between core depths of 653 and $604 \mathrm{~cm}$ (within RL3; Fig. 2), since this interval is bracketed by two radiocarbon dates $(15,160 \pm 70$ and $14,990 \pm 60$, respectively; Table 1$)$ displaying a time interval of $\sim 170{ }^{14} \mathrm{C}$ yr. To a first order, this radiocarbon time interval, being short, can be considered as a calendar time interval. We counted 192 red laminations (X-ray dark laminations) that fit the measured $\sim 170$ yrs, well supporting seasonal deposition for the red clayey with IRD laminations. As a result, the duration of each RL deposition was constrained by visually counting the X-ray dark laminations (the red laminations with IRD). We found durations of 162, 237, 263, and 221 years for the oldest to the youngest RL (RL4 to 1 in Fig. 2), respectively. RL4 onset was anchored at $17.2 \mathrm{kyr} B P$ (red dot in Fig. 3) by applying the sedimentation rate calculated between the last two TEX $_{86}$ /Hulu Cave tie points (Fig. 3). Between each discrete RL, as well as between the end of the RL1 to the onset of C2 (which corresponds to the Bølling-Allerød onset dated to $14.8 \mathrm{kyr}$ BP; Figs. 2 and 3), we assumed a constant sedimentation rate which resulted in a sedimentation rate of $94 \mathrm{~cm} / \mathrm{kyr}$, consistent with the mean sedimentation rate of the preceding glacial period $(90 \mathrm{~cm} / \mathrm{kyr})$.

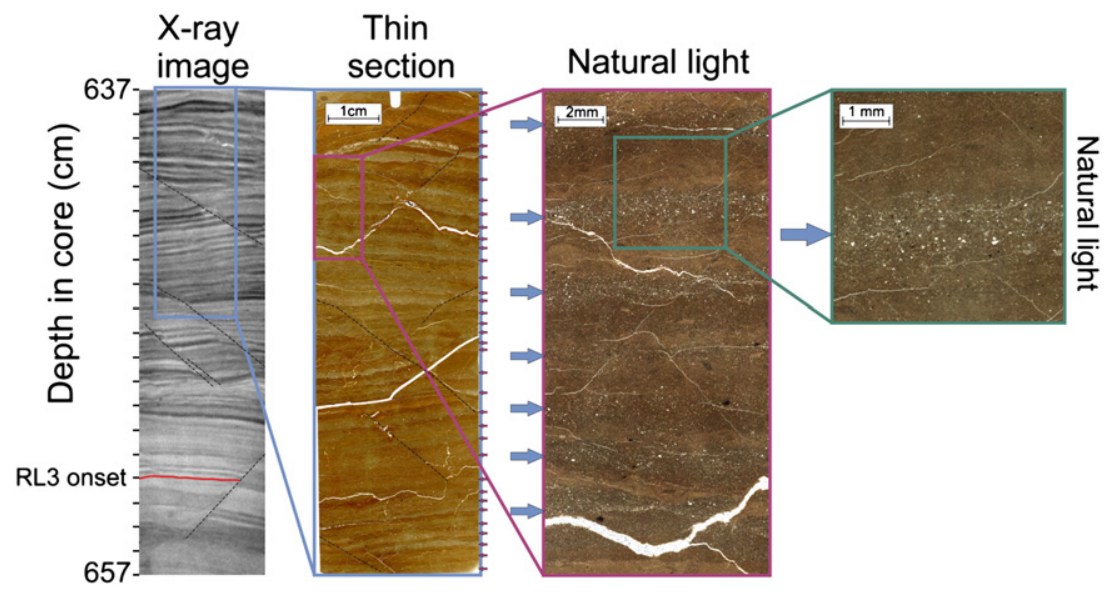

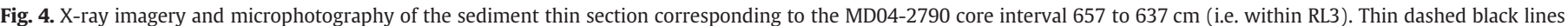

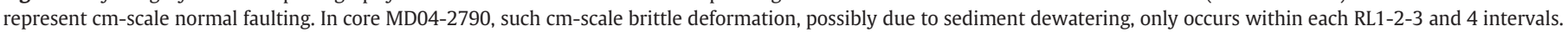

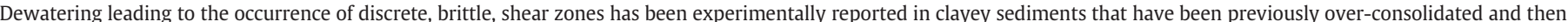

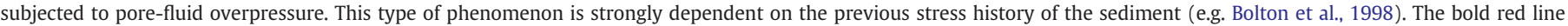

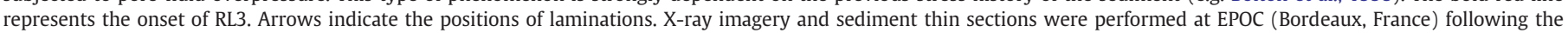
methods described in Zaragosi et al. (2006). 
Table 1

Black Sea "Lake" radiocarbon data.

\begin{tabular}{|c|c|c|c|c|c|c|c|c|}
\hline \# Lab number & $\begin{array}{l}\text { Depth } \\
\text { (cmbsf) }\end{array}$ & $\begin{array}{l}\text { Corresponding depth in } \\
\text { core MD04-2790 } \\
\text { (cmbsf) }\end{array}$ & $\begin{array}{l}\text { Sedimentary } \\
\text { subunit }^{\mathrm{a}}\end{array}$ & Sample type & $\begin{array}{l}\text { AMS }{ }^{14} \mathrm{C} \text { age } \\
(\text { yr BP }) \pm 1-\sigma\end{array}$ & $\begin{array}{l}\text { Tuned calendar age } \\
(\mathrm{yr} \mathrm{BP}) \pm 1-\sigma\end{array}$ & $\begin{array}{l}\Delta^{14} C \\
(\%) \pm 1-\sigma\end{array}$ & $\begin{array}{l}\text { Reservoir age } \\
\left({ }^{14} \mathrm{C} \text { yr }\right) \pm 1-\sigma\end{array}$ \\
\hline \multicolumn{9}{|c|}{ MD04-2790 (352 water depth; this study) } \\
\hline SacA 13276 & 125 & - & $\mathrm{T}$ & Candona sp. & $7640 \pm 30$ & - & $27 \pm 31^{\mathrm{b}}$ & $410 \pm 262^{b}$ \\
\hline SacA 7608 & 213 & - & GT1 & Dreissena sp. & $10,305 \pm 45$ & $11,591 \pm 99$ & $127 \pm 15$ & $253 \pm 59$ \\
\hline SacA 7609 & 247 & - & $\mathrm{C} 2$ & Dreissena sp. & $11,655 \pm 45$ & $13,213 \pm 148$ & $159 \pm 22$ & $304 \pm 181$ \\
\hline SacA 7610 & 257 & - & $\mathrm{C} 2$ & Dreissena sp. & $11,920 \pm 45$ & $13,483 \pm 189$ & $158 \pm 27$ & $309 \pm 215$ \\
\hline SacA 13277 & 275 & - & $\mathrm{C} 2$ & Dreissena sp. & $12,355 \pm 40$ & $13,827 \pm 137$ & $144 \pm 20$ & $370 \pm 155$ \\
\hline SacA 7611 & 300 & - & $\mathrm{C} 2$ & Dreissena sp. & $12,825 \pm 50$ & $14,201 \pm 150$ & $129 \pm 22$ & $554 \pm 131$ \\
\hline SacA 15497 & 336 & - & GT2 & Dreissena sp. & $12,835 \pm 45$ & $14,785 \pm 157$ & $210 \pm 24$ & $239 \pm 133$ \\
\hline SacA 13278 & 390 & - & GT2 & Dreissena sp. & $13,390 \pm 35$ & $15,345 \pm 218$ & $208 \pm 32$ & $538 \pm 158$ \\
\hline SacA 10311 & 405 & - & GT2 & Dreissena sp. & $13,540 \pm 50$ & $15,500 \pm 249$ & $209 \pm 37$ & $620 \pm 160$ \\
\hline SacA 13279 & 425 & - & RL & Dreissena sp. & $13,885 \pm 40$ & $15,679 \pm 284$ & $183 \pm 41$ & $885 \pm 164$ \\
\hline SacA $7612^{\mathrm{C}}$ & 444 & - & $\mathrm{RL}$ & Dreissena sp. & $14,930 \pm 60$ & $15,742 \pm 284$ & $47 \pm 37$ & $1895 \pm 163$ \\
\hline SacA 7613 & 490 & - & $\mathrm{RL}$ & Dreissena sp. & $14,200 \pm 50$ & $15,908 \pm 288$ & $169 \pm 41$ & $1084 \pm 158$ \\
\hline SacA 10312 & 497 & - & $\mathrm{RL}$ & Dreissena sp. & $14,320 \pm 60$ & $15,980 \pm 307$ & $162 \pm 44$ & $1161 \pm 175$ \\
\hline SacA 13280 & 500 & - & RL & Dreissena sp. & $14,290 \pm 60$ & $16,012 \pm 311$ & $171 \pm 45$ & $1108 \pm 181$ \\
\hline SacA 7614 & 604 & - & $\mathrm{RL}$ & Dreissena sp. & $14,990 \pm 60$ & $16,497 \pm 373$ & $138 \pm 52$ & $1406 \pm 330$ \\
\hline SacA 7615 & 653 & - & $\mathrm{RL}$ & Dreissena sp. & $15,160 \pm 70$ & $16,688 \pm 373$ & $140 \pm 52$ & $1465 \pm 343$ \\
\hline SacA 7616 & 740 & - & G & Dreissena sp. & $15,820 \pm 60$ & $17,425 \pm 365$ & $148 \pm 51$ & $1570 \pm 377$ \\
\hline SacA 13281 & 775 & - & G & Dreissena sp. & $16,150 \pm 50$ & $17,985 \pm 367$ & $179 \pm 53$ & $1327 \pm 348$ \\
\hline SacA 10313 & 830 & - & G & Dreissena sp. & $16,710 \pm 70$ & $18,913 \pm 179$ & $231 \pm 29$ & $990 \pm 255$ \\
\hline SacA 10314 & 1010 & - & G & Dreissena sp. & $18,340 \pm 70$ & $20,662 \pm 483$ & $241 \pm 73$ & $996 \pm 409$ \\
\hline SacA 7617 & 1146 & - & G & Dreissena sp. & $19,530 \pm 80$ & $21,883 \pm 169$ & $241 \pm 28$ & $1199 \pm 183$ \\
\hline SacA 15498 & 1209 & - & G & Dreissena sp. & $19,820 \pm 80$ & $22,793 \pm 339$ & $336 \pm 56$ & $748 \pm 323$ \\
\hline SacA 13282 & 1322 & - & G & Dreissena sp. & $20,820 \pm 70$ & $24,372 \pm 161$ & $428 \pm 30$ & $400 \pm 199$ \\
\hline SacA $13283^{c}$ & 1395 & - & G & Dreissena sp. & $22,230 \pm 80$ & $25,284 \pm 200$ & $338 \pm 35$ & $1071 \pm 188$ \\
\hline SacA 13284 & 1554 & - & G & Dreissena sp. & $22,380 \pm 110$ & $27,270 \pm 175$ & $670 \pm 42$ & $-196 \pm 196$ \\
\hline SacA 13285 & 1612 & - & G & Dreissena sp. & $23,010 \pm 90$ & $27,240 \pm 310$ & $634 \pm 64$ & $28 \pm 361$ \\
\hline SacA 15498 & 1719 & - & G & Dreissena sp. & $23,560 \pm 100$ & $28,259 \pm 210$ & $625 \pm 46$ & $111 \pm 307$ \\
\hline SacA $15499^{d}$ & 1827 & - & G & Dreissena sp. & $24,020 \pm 100$ & $29,748 \pm 207$ & $837 \pm 51$ & - \\
\hline SacA $10315^{d}$ & 1865 & - & G & Dreissena sp. & $24,680 \pm 120$ & $30,199 \pm 189$ & $787 \pm 49$ & - \\
\hline SacA $15501^{d}$ & 1873 & - & G & Dreissena sp. & $24,360 \pm 100$ & $30,319 \pm 191$ & $887 \pm 49$ & - \\
\hline \multicolumn{9}{|c|}{ BLKS9810 (378 m water depth; Major et al., 2002) } \\
\hline ETH-23298 & 94.5 & 223 & GT1 & Turricaspia & $10,640 \pm 80$ & $12,123 \pm 214$ & $153 \pm 32$ & $291 \pm 155$ \\
\hline ETH-23299 & 118.5 & 239 & $\mathrm{C} 2$ & Dreissena & $11,410 \pm 110$ & $12,984 \pm 103$ & $162 \pm 22$ & $308 \pm 156$ \\
\hline ETH-23300 & 154.5 & 296 & $\mathrm{C} 2$ & Dreissena & $12,790 \pm 110$ & $14,142 \pm 150$ & $126 \pm 26$ & $573 \pm 175$ \\
\hline ETH-23301 & 186.5 & 346 & GT2 & Dreissena & $12,920 \pm 100$ & $14,890 \pm 159$ & $213 \pm 28$ & $305 \pm 170$ \\
\hline \multicolumn{9}{|c|}{ GeoB 7608-1 (1202 m water depth; Bahr et al., 2005) } \\
\hline KIA 21464 & 34 & 125 & $\mathrm{~T}$ & Ostracods & $7735 \pm 50$ & - & $15 \pm 31^{\mathrm{b}}$ & $505 \pm 265^{\mathrm{b}}$ \\
\hline KIA 21463 & 88 & 219 & GT1 & Gastropod & $11,460 \pm 70$ & $11,914 \pm 119$ & $15 \pm 17$ & $1252 \pm 83$ \\
\hline KIA 21461 & 158 & 335.5 & $\mathrm{C} 2$ & Gastropod & $13,350 \pm 80$ & $14,780 \pm 157$ & $134 \pm 24$ & $761 \pm 136$ \\
\hline KIA 21866 & 436 & 723 & RL & Gastropod & $16,360 \pm 70$ & $17,140 \pm 365$ & $36 \pm 47$ & $2389 \pm 383$ \\
\hline \multicolumn{9}{|c|}{ MD04-2760 and MD04-2788 (1226 and 1224 water depth; Kwiecien et al., 2008) } \\
\hline KIA 26699 & $373^{\mathrm{e}}$ & 133 & $\mathrm{~T}$ & Gastropods & $8820 \pm 55$ & - & $-14 \pm 23^{\mathrm{b}}$ & $730 \pm 132^{\mathrm{b}}$ \\
\hline KIA 25679 & $373^{e}$ & 133 & $\mathrm{~T}$ & Ostracods & $8910 \pm 45$ & - & $-25 \pm 22^{\mathrm{b}}$ & $820 \pm 128^{b}$ \\
\hline KIA 26700 & $540^{e}$ & 219 & GT1 & Gastropods & $11,105 \pm 60$ & $11,891 \pm 115$ & $58 \pm 17$ & $907 \pm 76$ \\
\hline KIA 26701 & $653^{\mathrm{e}}$ & 297 & $\mathrm{C} 2$ & Gastropods & $13,050 \pm 70$ & $14,146 \pm 150$ & $91 \pm 22$ & $824 \pm 147$ \\
\hline KIA 28419 & $679^{e}$ & 326 & $\mathrm{C} 2$ & Ostracods & $13,220 \pm 70$ & $14,617 \pm 156$ & $130 \pm 24$ & $722 \pm 135$ \\
\hline KIA 25676 & $1248^{e}$ & 659 & RL & Ostracods & $14,800 \pm 100$ & $16,752 \pm 371$ & $202 \pm 56$ & $1066 \pm 348$ \\
\hline KIA 25684 & $1384^{e}$ & 723 & $\mathrm{RL}$ & Ostracods & $16,120 \pm 90$ & $17,140 \pm 365$ & $69 \pm 49$ & $2132 \pm 386$ \\
\hline KIA 25685 & $1519^{e}$ & 789 & G & Ostracods & $17,090 \pm 110$ & $18,195 \pm 384$ & $77 \pm 52$ & $2047 \pm 410$ \\
\hline KIA 25686 & $2105^{e}$ & 1079 & G & Ostracods & $19,390 \pm 110$ & $21,243 \pm 315$ & $169 \pm 47$ & $1558 \pm 289$ \\
\hline KIA 25697 & $2305^{e}$ & 1236 & G & Ostracods & $20,240 \pm 130$ & $23,226 \pm 355$ & $337 \pm 61$ & $762 \pm 339$ \\
\hline KIA 25754 & $2507^{e}$ & 1390 & G & Gastropods & $21,030 \pm 190$ & $25,207 \pm 185$ & $540 \pm 50$ & $-93 \pm 238$ \\
\hline KIA 25688 & $2507^{e}$ & 1390 & G & Ostracods & $21,460 \pm 140$ & $25,207 \pm 185$ & $459 \pm 41$ & $336 \pm 219$ \\
\hline KIA 2578 & $2737^{e}$ & 1496 & G & Ostracods & $22,340 \pm 190$ & $26,665 \pm 196$ & $560 \pm 52$ & $186 \pm 267$ \\
\hline
\end{tabular}

a See caption of Fig. 2.

b Calculated as described in Soulet et al. (2011).

c Samples in clear age inversion.

d Inconsistent $\Delta^{14} \mathrm{C}$.

e Middle of the sieved interval ( 10 or $20 \mathrm{~cm}$; see Kwiecien et al., 2008).

Sedimentary transitions from lacustrine to marine environments were characterized by steep decreases in the XRF-Ca intensity and the $\mathrm{CaCO}_{3}$ content that occurred in the MD04-2790 core at a depth of $133 \mathrm{cmbsf}$ (Fig. 2; subunit T). The onset of Black Sea sapropel deposition was characterized by the occurrence of thinly laminated aragonite layers beginning at a depth of $124 \mathrm{cmbsf}$ (Fig. 2; subunit A), and visible in the XRF-Ca intensity as thin discrete peaks (Fig. 2). The feature is concomitant with a rapid increase in TOC (Fig. 2). A review of the various sedimentological and geochemical signatures and the associated radiocarbon ages of the two boundaries throughout the various Black Sea sedimentary environments (from the basin to the coastal plain) allowed Soulet et al. (2011) to determine the following atmospheric radiocarbon ages: $8090 \pm 120{ }^{14} \mathrm{C}$ yr BP for the steep decrease in XRF-Ca and $\mathrm{CaCO}_{3}$, and $7230 \pm 260{ }^{14} \mathrm{C}$ yr BP for the onset of sapropel deposition leading to calibrated ages of $8995 \pm 145$ and $8080 \pm 250$ yr BP, respectively. 
Calendar Age (yr BP)

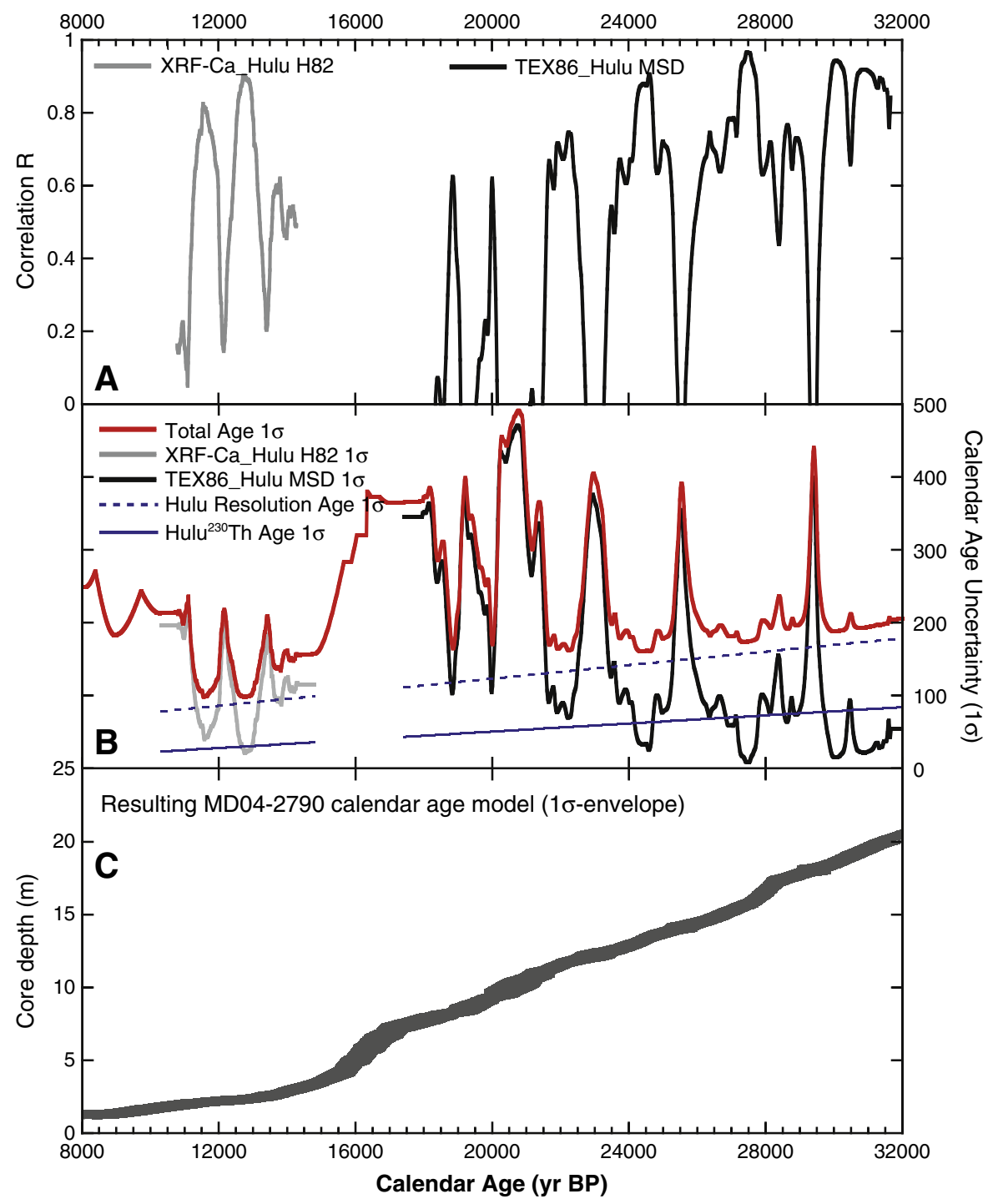

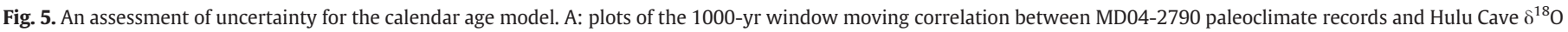

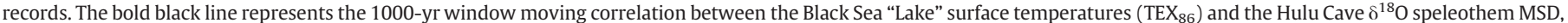

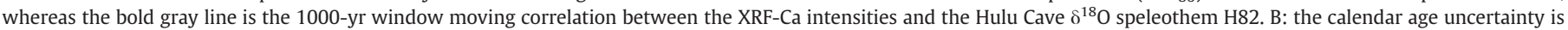

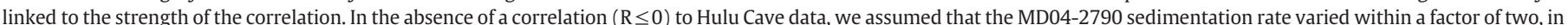

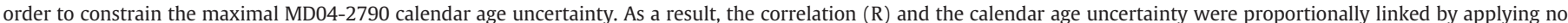

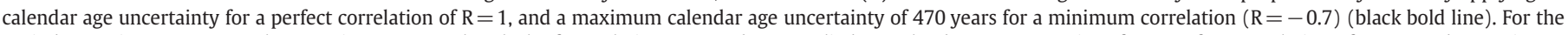

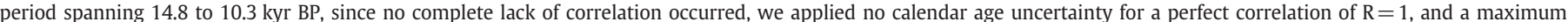

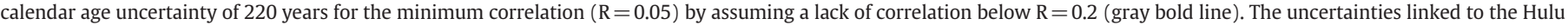

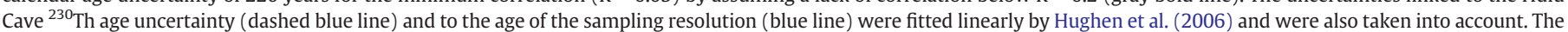

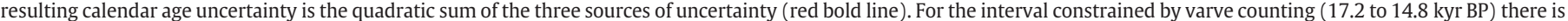

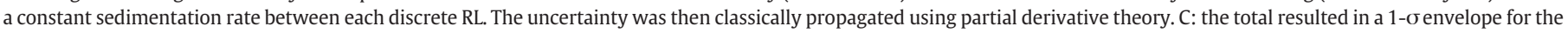
MD04-2790 age model.

For the intervals of the age model derived from tuning ( 32 to 17.7 and 14.8 to $10 \mathrm{kyr} \mathrm{BP}$ ), uncertainties were propagated following the approach of Hughen et al. (2006). The approach mainly relies upon the assumption that the age model uncertainty is linearly linked to the correlation coefficient evolution between MD04-2790 and the Hulu Cave records (Fig. 5). Otherwise, the age model uncertainty was propagated using the uncertainties of the tie points through the partial derivative theory of error propagation (Fig. 5).

\subsubsection{Radiocarbon dates}

Measurements were performed on shells of the benthic bivalve Dreissena sp. Only one radiocarbon measurement was derived from a monospecific ostracod sample (Candona sp.). Measurements were performed by Accelerator Mass Spectrometry at the "Laboratoire de Mesure du Carbone 14" (Saclay, France). The resulting AMS ${ }^{14} \mathrm{C}$ ages were calculated following the method of Mook and Van der Plicht (1999).

In order to enlarge the radiocarbon dataset, we compared our XRF$\mathrm{Ca} / \mathrm{CaCO}_{3}$ profiles with those of the following neighboring cores: MD04-2760/88 (Kwiecien et al., 2008), GeoB 7608-1 (Bahr et al., 2005), and BLKS 9810 (Major et al., 2002) (see Fig. 1 for core locations). Between the RL and C1 sedimentary intervals (Fig. 2), geochemical features were so prominent that the different records are easily correlable. For interval G (Fig. 2), even if meaningful, the variability in the different geochemical profiles was low. As a result, we only correlated our XRF-Ca record to the XRF-Ca record from core 
MD04-2760/88, which displayed the highest measurement resolution (Kwiecien et al., 2008; Fig. 6). The approach allowed us to transfer original depths of the previously published radiocarbon dates to the MD04-2790 core depth (Table 1). Here, we report 51 radiocarbon ages for which 30 are original.

\subsubsection{Black Sea "Lake" reservoir ages and $\Delta^{14} \mathrm{C}$}

2.2.5.1. Reservoir age calculation. We obtained the calendar age of each ${ }^{14} \mathrm{C}$-dated sample using the tuned chronology (see Section 2.2.3). Each pair of calendar and ${ }^{14} \mathrm{C}$ dates allowed us to calculate an associated reservoir age. The core principle of the approach is illustrated in Fig. 7.

The statistical method used to calculate the reservoir age (R) and its associated uncertainties $\left(\sigma_{R}\right)$ for a pair of calendar $\left(t_{\text {calend }} \pm \sigma_{\text {calend }}\right.$ in yr BP) and radiocarbon ( $\mathrm{t}_{\mathrm{rad}} \pm \sigma_{\mathrm{rad}}$ in ${ }^{14} \mathrm{C} \mathrm{yr} \mathrm{BP}$ ) dates is based on the Bayesian framework (Buck et al., 1996). In this framework, prior knowledge is our knowledge regarding quantities "before" the statistical inference (or inversion) and had to be translated under the form of the distributions. For our problem, we designed the distributions as $p(R)$ for $R$ and $p\left(T_{\text {rad }}\right)$ for the actual - not perfectly known - radiocarbon age $T_{\text {rad }}$. We had a very weak knowledge of the reservoir age. We then choose $\mathrm{p}(\mathrm{R})=\mathrm{U}(\mathrm{R} ;-10,000 ; 10,000)$ (i.e. a uniform distribution for $\mathrm{R}$ spanning $-10,000$ to $10,000 \mathrm{yr}$ ). In contrast, we had a relatively strong knowledge of the radiocarbon age from laboratory measurements, that we translated by taking $\mathrm{p}\left(\mathrm{T}_{\mathrm{rad}}\right)=\mathrm{N}\left(\mathrm{T}_{\mathrm{rad}} ; \mathrm{t}_{\mathrm{rad}}, \sigma_{\text {rad }}\right)$ (i.e. a Gaussian distribution for $\mathrm{T}_{\text {rad, }}$, centered on $t_{\text {rad }}$, with a standard deviation $\sigma_{\text {rad }}$ ).

We then related $R$ and $T_{\text {rad }}$ to an auxiliary variable called $T_{\text {calib }}$ which represents the calibrated age corresponding to $R$ and $T_{r a d}$ through the classical "radiocarbon calibration process". The calibrated age is itself related to $T_{\text {calend, }}$, the calendar age of the sample. We used a first distribution of the calibrated age given both the reservoir age and the radiocarbon age, $\mathrm{p}\left(\mathrm{T}_{\text {calib }} \mid \mathrm{R}, \mathrm{T}_{\mathrm{rad}}\right)$. The distribution is defined by the calibration program used, (here, Calib6.0.1; http:// intcal.qub.ac.uk/calib/). The second distribution $\mathrm{p}\left(\mathrm{T}_{\text {calend }} \mid \mathrm{T}_{\text {calib }}\right)$ links the calibrated age $\mathrm{T}_{\text {calib }}$ with the calendar age $\mathrm{T}_{\text {calend }}$. We used $\mathrm{p}\left(\mathrm{T}_{\text {calend }} \mid \mathrm{T}_{\text {calib }}\right)=\mathrm{N}\left(\mathrm{T}_{\text {calend }} ; \mathrm{T}_{\text {calib}}, \sigma_{\text {calend }}\right)$ (i.e. a Gaussian distribution for $\mathrm{T}_{\text {calend }}$ centered on $\mathrm{T}_{\text {calib }}$ and with a standard deviation equal to $\left.\sigma_{\text {calend }}\right)$. In practice, the symmetric relationship between $T_{\text {calend }}$ and $\mathrm{T}_{\text {calib }}$ measures the closeness between both quantities and allows one to "select" $\mathrm{T}_{\text {calib }}$ and the associated $\mathrm{R}$ that best corresponds to the "measured" $T_{\text {calend }}$ value, noted $t_{\text {calend. }}$. Bayes formula allowed us to invert our "forward" model providing the posterior distribution of $\mathrm{R}, \mathrm{T}_{\text {rad }}$, and $\mathrm{T}_{\text {calib }}$ given $\mathrm{t}_{\text {calend }}$, its uncertainty ( $\left.\sigma_{\text {calend }}\right)$, and prior information, as follows:

$p\left(R, T_{\text {rad }}, T_{\text {calib }} \mid t_{\text {calend }}\right)=\frac{p(R) \cdot p\left(T_{\text {rad }}\right) \cdot p\left(T_{\text {calib }} \mid R, T_{\text {rad }}\right) \cdot p\left(t_{\text {calend }} \mid T_{\text {calib }}\right)}{\int p(R) \cdot p\left(T_{\text {rad }}\right) \cdot p\left(T_{\text {calib }} \mid R, T_{\text {rad }}\right) \cdot p\left(T_{\text {calend }} \mid T_{\text {calib }}\right) \cdot d R \cdot d T_{\text {calib }} \cdot d T_{\text {rad }}}$.

The distribution, called the posterior, carries all information regarding $\mathrm{R}$ from the posited prior, the model, and the data. Since the denominator does not depend on the variables of interest $\left(R, T_{r a d}\right.$, and $\mathrm{T}_{\text {calib }}$ ), it is a normalizing constant for the distribution defined by the numerator. As usual for Bayesian computation, we used a simpler proportional relationship and kept in mind that the defined posterior distribution must be renormalized so that its integral was 1 . Thus, we simply noted the following:

$p\left(R, T_{\text {rad }}, T_{\text {calib }} \mid t_{\text {calend }}\right) \propto p(R) \cdot p\left(T_{\text {rad }}\right) \cdot p\left(T_{\text {calib }} \mid R, T_{\text {rad }}\right) \cdot p\left(t_{\text {calend }} \mid T_{\text {calib }}\right)$.

We then integrated over $\mathrm{T}_{\text {rad }}$ and $\mathrm{T}_{\text {calib }}$ in order to obtain the posterior only for $\mathrm{R}$, as follows:

$$
p\left(R \mid t_{\text {calend }}\right) \propto p(R) \cdot \int p\left(T_{\text {rad }}\right) \cdot p\left(T_{\text {calib }} \mid R, T_{\text {rad }}\right) \cdot p\left(t_{\text {calend }} \mid T_{\text {calib }}\right) \cdot d T_{\text {rad }} \cdot d T_{\text {calib }} .
$$

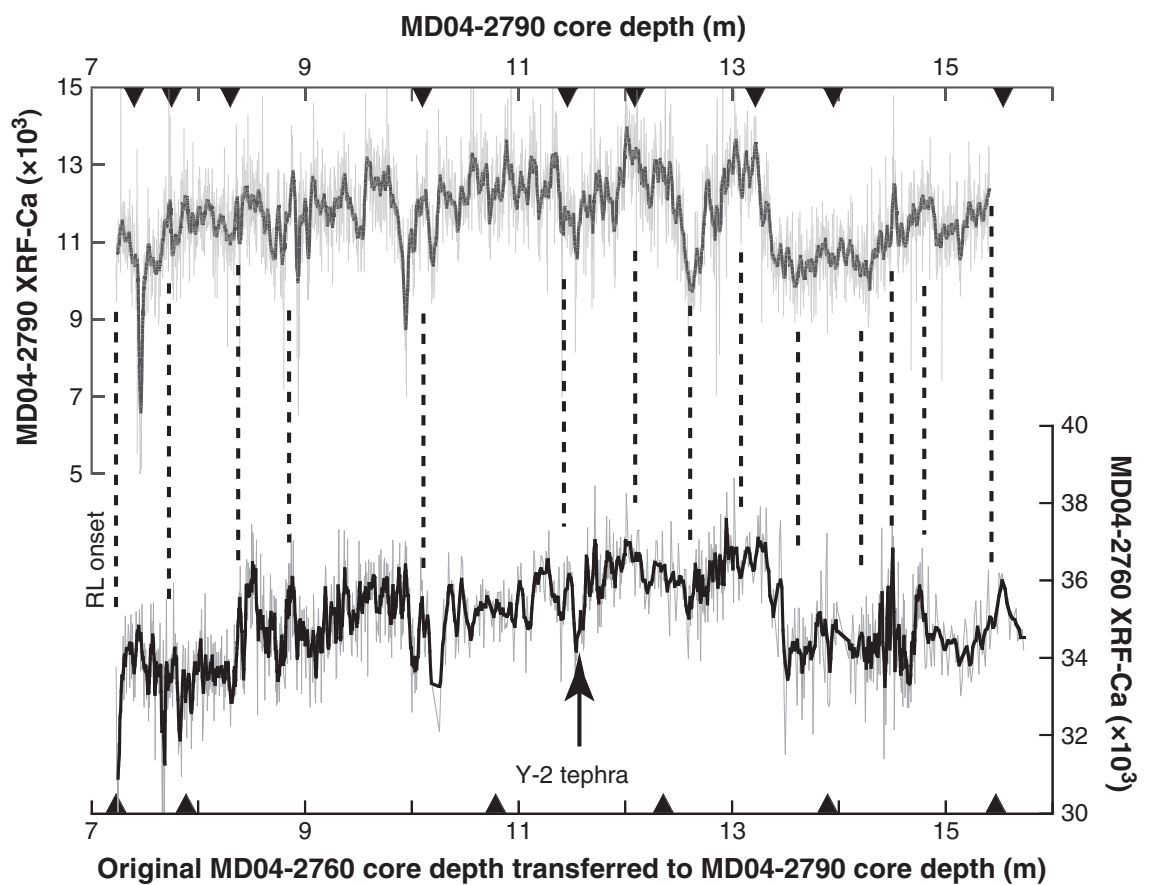

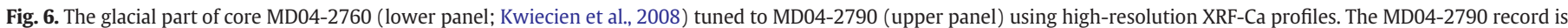

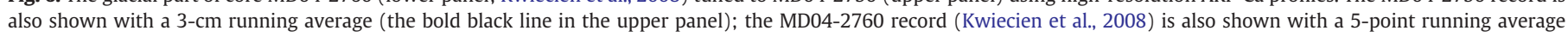

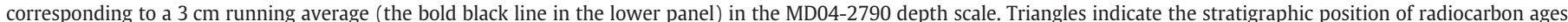

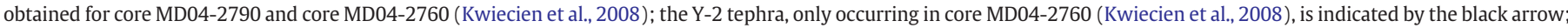

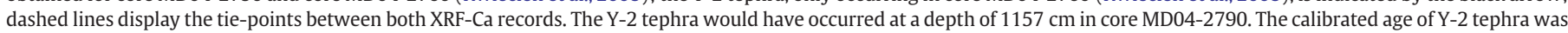
$21,770 \pm 500$ cal. yr BP (Kwiecien et al., 2008), in perfect agreement with the calendar age for a depth of $1157 \mathrm{~cm}(21,995 \pm 170 \mathrm{yr}$ BP), as obtained using our tuning. 

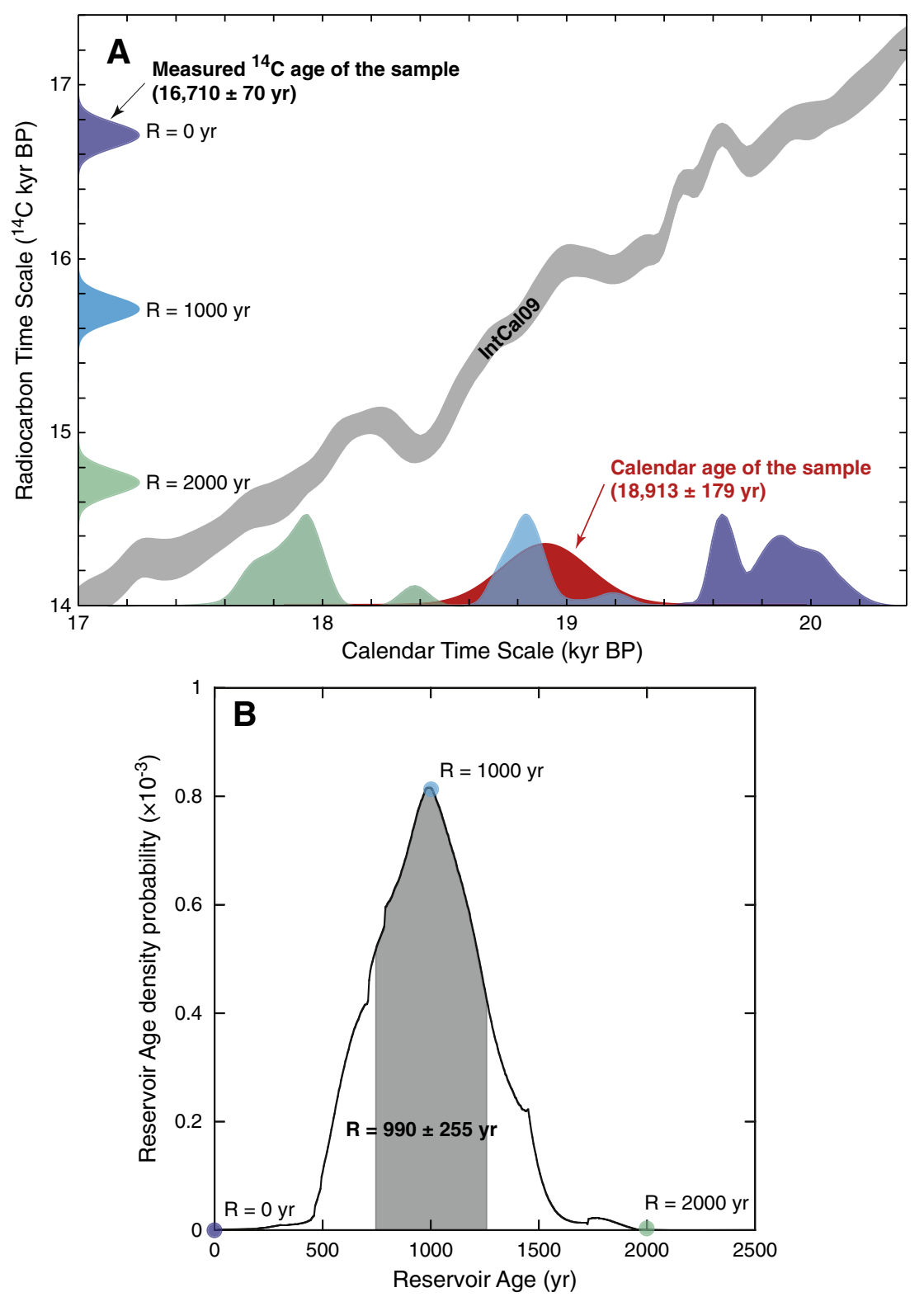

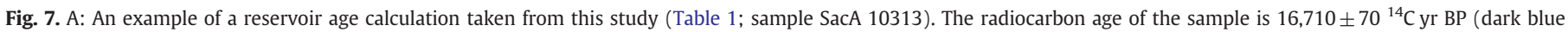

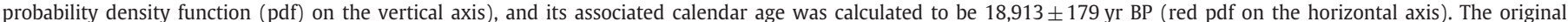

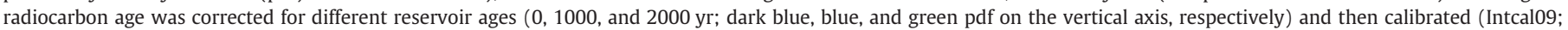

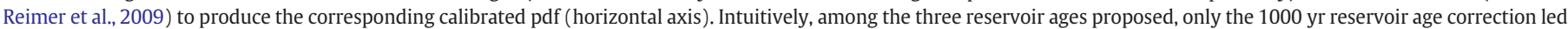

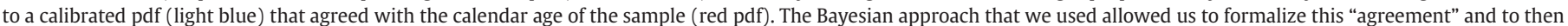

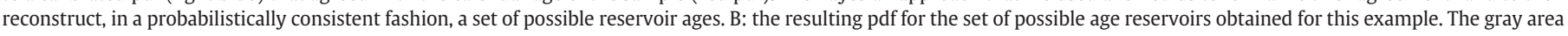
is defined as the mean of the reservoir age plus or minus one standard deviation $( \pm 1 \sigma)$.

A numerical approximation of the distribution in Eq. (1) was obtained by computing the integral for a grid of $R$ values. We noted $R_{j}$ as a value of this grid, with $j=1$..n. For each $R_{j}$, we then approximated $I\left(R_{j}\right)=p\left(R_{j} \mid t_{\text {calend }}\right)$ as follows:

1. $t_{\text {rad }}$ was corrected for $R_{j}$,

2. The value was calibrated with a standard error of $\sigma_{\text {rad }}$ using IntCal09 (Reimer et al., 2009). We used Calib6.0.1 (http://intcal. qub.ac.uk/calib/) which provided, as output, a weighted set of $\mathrm{K}$ Gaussian distributions. We indexed with $\mathrm{k}=1 . . \mathrm{K}$ the weights $\mathrm{w}_{\mathrm{k}}$ between 0 and 1 and the parameters that defined the distributions, $\mathrm{m}_{\mathrm{k}}$ and $\sigma_{\mathrm{k}}$. Numerical integration was performed by discretising the space of $\mathrm{T}_{\text {calib }}$ over, for example, $6 \sigma_{\text {calib. Note that }} t_{\text {calib,i, }}$, $\mathrm{i}=1 . . \mathrm{M}$, is a value of this grid. The integral for a given $R_{j}$ is, therefore, as follows:

$I\left(R_{j}\right)=\sum_{i=1}^{M}\left[\left(\sum_{k=1}^{K} w_{k} \cdot \mathrm{N}\left(t_{\text {calib }, i} ; m_{k}, \sigma_{k}\right)\right) \cdot \mathrm{N}\left(t_{\text {calend }} ; t_{\text {calib }, i}, \sigma_{\text {calend }}\right) \cdot\left(t_{\text {calib }, i+1}-t_{\text {calib }, i}\right)\right]$,

where $\mathrm{N}(\mathrm{a} ; \mathrm{b}, \mathrm{c})$ indicates a Gaussian distribution evaluated at point $\mathrm{a}$, with a mean $\mathrm{b}$ and a standard deviation $\mathrm{c}$. The posterior density of the reservoir age is the following:

$$
p\left(R \mid t_{\text {rad }}, t_{\text {calend }}\right)=\sum_{j=1}^{n}\left(\frac{\delta\left(R_{j}\right) \cdot I\left(R_{j}\right)}{\sum_{j=1}^{n} I\left(R_{j}\right)}\right)
$$


where $\delta$ is the Dirac mass function and the denominator is the normalizing constant. For convenience, in the following discussion, the discrete distributions (shown in a later equation and in Fig. 7) are summarized as the form of a mean $\pm 1 \sigma$ (Table 1 ).

From 50 to $26 \mathrm{kyr} \mathrm{BP}$, the atmospheric Intcal09 calibration curve is quasi-exclusively constructed using the marine-derived record from the Cariaco Basin tuned to the ${ }^{230} \mathrm{Th}$-dated $\delta^{18} \mathrm{O}$ record from the Hulu Cave speleothems (Hughen et al., 2006; Reimer et al., 2009). Since we used Intcal09 in the reservoir age calculation process, the same timescale reference had to be chosen in order to tune our high-resolution geochemical dataset.

2.2.5.2. $\Delta^{14} C$ calculation. The $\Delta^{14} \mathrm{C}$ value (in \%o) represents, at calendar age $\left(\mathrm{t}_{\text {calend }}\right)$, the difference between the measured ${ }^{14} \mathrm{C} /{ }^{12} \mathrm{C}$ and the expected atmospheric ${ }^{14} \mathrm{C} /{ }^{12} \mathrm{C}$ if radiocarbon production had remained constant at the measured value in 1950 (Stuiver and Polach, 1977). The $\Delta^{14} \mathrm{C}$ (in \%) of the Black Sea "Lake" (Table 1) is calculated as follows: $\Delta^{14} \mathrm{C}=1000 \cdot\left(\frac{\exp \left(\frac{t_{\text {calend }}}{8267}\right)}{\exp \left(\frac{t_{\text {rad }}}{8033}\right)}-1\right)$.

Both the reconstructed reservoir ages and the $\Delta^{14} \mathrm{C}$ may depend on Black Sea "Lake" water depth. Since cores MD04-2790 and BLKS 9810 (Major et al., 2002) were retrieved from the upper water column ( 350 mbsl; meters below sea level), whereas cores MD04-2760/88 (Kwiecien et al., 2008) and GeoB 7608-1 (Bahr et al., 2005) were retrieved in the intermediate water column $(\sim 1200 \mathrm{mbsl})$, a possible water-depth dependent decoupling in the reservoir age and $\Delta^{14} \mathrm{C}$ could be explored.

\section{Results}

The original ${ }^{14} \mathrm{C}$ profile displays two main linear trends between 120 and 300 cmbsf (centimeters below sea floor) and between 400 and $1900 \mathrm{cmbsf}$ (Fig. 8). Among the 30 original AMS ${ }^{14} \mathrm{C}$ measure-

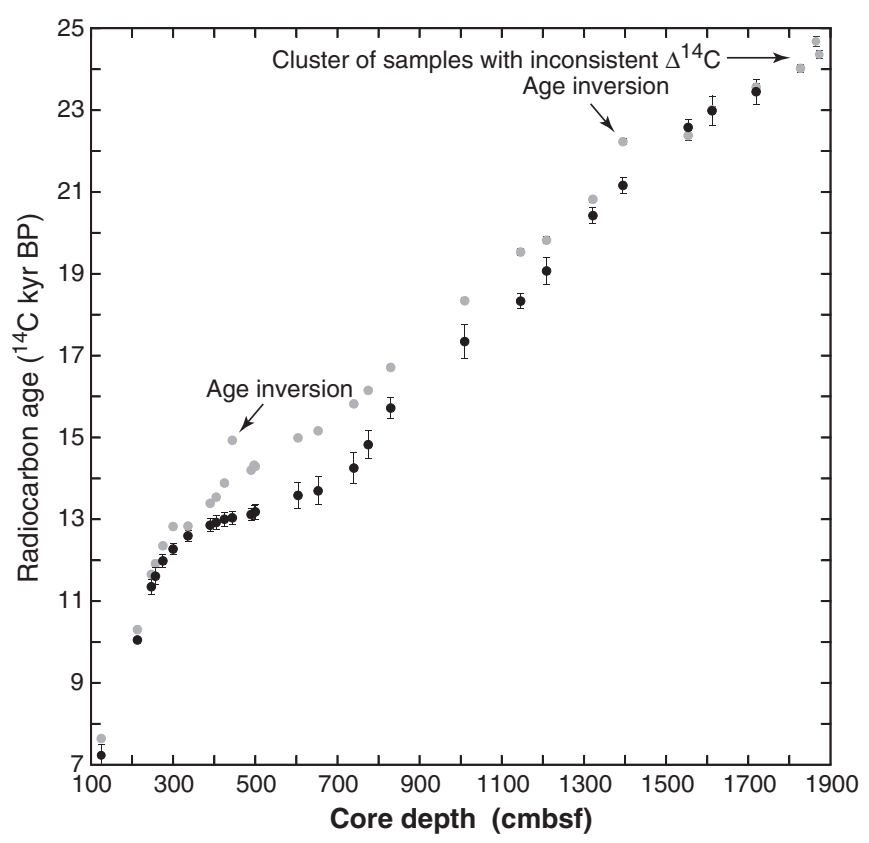

Fig. 8. The profile of the original ${ }^{14} \mathrm{C}$ ages obtained from core MD04-2790, plotted against core depth (gray dots). The same profile with original ${ }^{14} \mathrm{C}$ ages corrected for reconstructed reservoir ages (black dots). ments we report here, only two were found in a clear age inversion (Fig. 8; Table 1). Fig. 8 also shows the profile of the original radiocarbon ages corrected for the calculated reservoir ages. The corrected profile shows prominent differences as compared to the original profile. The observed differences are likely linked to drastic changes in sedimentation rates. In the original profile, these changes were hidden by the reservoir ages.

The $\Delta^{14} \mathrm{C}$ and the reservoir ages are shown in Fig. 9 and in Table 1 . The calculated $\Delta^{14} \mathrm{C}$ values are systematically lower than values for atmospheric $\Delta^{14} C$ (Fig. 9), indicating that the radiocarbon content within the Black Sea "Lake" was lower than for the contemporary atmosphere. The result indicates that the Black Sea "Lake" exhibited a positive reservoir age throughout the entire record. The $\Delta^{14} \mathrm{C}$ values from three samples were higher than the atmospheric reference (Fig. 9). The corresponding samples were of poor quality (small coquinas and low weights) which could have induced modern radiocarbon contamination during the procedural treatment prior to the radiocarbon analysis. Therefore, these samples were excluded from the reservoir age calculations and from the discussion.

Prior to $26 \mathrm{kyr}$ BP, the reservoir age values were constant within an uncertainty of $155 \pm 100 \mathrm{yr}$ (weighted mean by variance) (Fig. 9 and Table 1), and increased after 26 kyr BP (near HE2 onset). Around $23 \mathrm{kyr}$ BP (near the end of HE2), deep and shallow water reservoir ages progressively decoupled, reaching values of $\sim 2000 \mathrm{yr}$ and $\sim 1500 \mathrm{yr}$, respectively, at $17.2 \mathrm{kyr}$ BP (Fig. 9). During HE1, the reservoir age quickly dropped towards values of $\sim 250 \mathrm{yr}$ before the onset of the Bølling-Allerød (Fig. 9). The onset of the Bølling-Allerød is characterized by an instantaneous increase in the reservoir age of $500 \mathrm{yr}$, reaching $\sim 750 \mathrm{yr}$ (Fig. 9). During the Bølling-Allerød, deep water reservoir ages increased until values of $\sim 900 \mathrm{yr}$ during the Younger Dryas, whereas shallow water reservoir ages displayed an opposite trend reaching stable values of $\sim 280$ from $13.8 \mathrm{kyr}$ BP to the end of the Younger Dryas cold event (Fig. 8). At the lacustrine to marine transition, the reservoir age was approximately $300 \mathrm{yr}$ (Soulet et al., 2011).

\section{Discussion}

The reservoir age (i.e. the ${ }^{14} \mathrm{C}$ content difference between water $\Sigma \mathrm{CO}_{2}$ and contemporaneous atmospheric $\mathrm{CO}_{2}$ ) results from a balance between the input of atmospheric ${ }^{14} \mathrm{C}$ into the reservoir and its removal by export processes and radiodecay within the reservoir (e.g. Bard, 1988; Siegenthaler et al., 1980; Stuiver et al., 1986). In the open ocean, climate-related changes in atmospheric and oceanic parameters, such as atmospheric $\mathrm{pCO}_{2}$, the wind speed, the ocean's free surface, and other variables drive changes in the reservoir age. However, oceanic circulation is, by far, the main driver of changes in reservoir age (e.g. Andrée et al., 1986a; Bard, 1988; Bondevik et al., 2006; Siani et al., 2001; Stuiver et al., 1986).

In lakes, anomalously high reservoir ages, as compared to those commonly measured in the global ocean, have been reported (e.g. Andrée et al., 1986b; Ascough et al., 2010; Kwiecien et al., 2008; Stein et al., 2004; Zhou et al., 2009). A common explanation for this phenomenon is the Hard Water Effect (HWE) (i.e. $\Sigma^{14} \mathrm{CO}_{2}$ dilution by radioactively "dead" $\Sigma \mathrm{CO}_{2}$ originating from rock weathering that is transported to lakes by rivers (e.g. Andrée et al., 1986b; Broecker and Olson, 1961; Kwiecien et al., 2008; Mangerud, 1972; Ross and Degens, 1974). Therefore, HWE in lakes is related to the lake "dead" $\Sigma \mathrm{CO}_{2}$ content ("dead" dissolved inorganic carbon), itself being related to both riverine runoff and the riverine content in "dead" $\Sigma \mathrm{CO}_{2}$, as well as to the lake water budget. In the following we qualitatively explain how regional climate, by influencing the lake water budget and riverine runoff, as well as rock weathering, is able to change the Hard Water Effect and, as a result, the basin reservoir age. 
Calendar Age (yr BP)

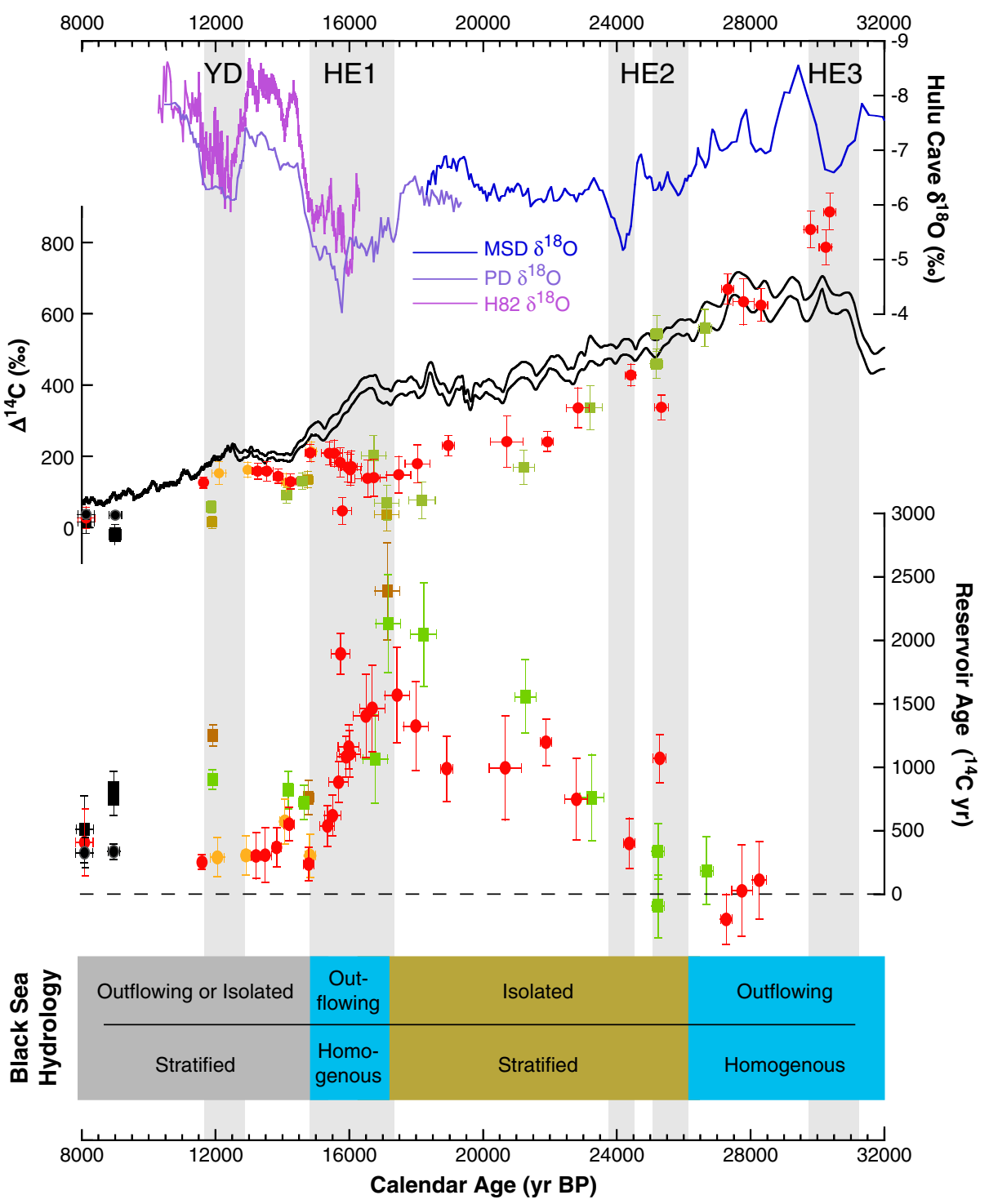

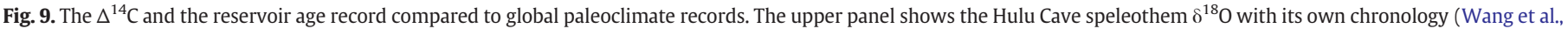

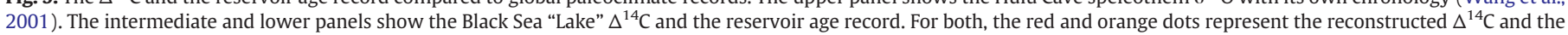

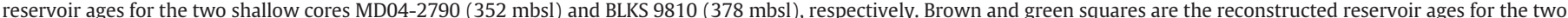

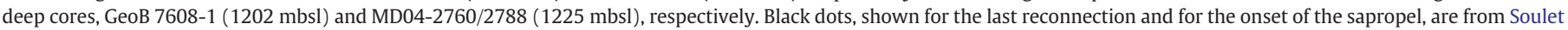
et al. (2011). Black Sea "Lake" $\Delta^{14} C$ values were compared to the atmospheric IntCal09 $\Delta^{14} C 1 \sigma$-envelope (bold black lines) (Reimer et al., 2009).

\subsection{The Black Sea "Lake" water budget as a driver for reservoir age} changes

The basin water budget influences the Hard Water Effect (HWE) and, therefore, reservoir ages. In fact, in strictly enclosed lakes (lakes without outflow) with an evaporative water budget (i.e. evaporation exceeding precipitation and runoff), the "dead" $\Sigma \mathrm{CO}_{2}$ brought by rivers continuously accumulates and dilutes basin $\Sigma^{14} \mathrm{CO}_{2}$, thereby continuously increasing HWE and reservoir ages. A lake water budget shift from a negative to a positive state (precipitation and runoff exceeding evaporation) leads to a decrease in lake "dead" $\Sigma \mathrm{CO}_{2}$ by dilution. An attendant decrease in lake $\mathrm{pCO}_{2}$ is expected to increase the $\mathrm{CO}_{2}$ flux from the atmosphere to the lake, leading to an increase in lake $\Sigma^{14} \mathrm{CO}_{2}$. The coupled effect leads to a decrease in the HWE, and, therefore, in reservoir age. If the positive water budget persists until it leads the lake level to its outlet, towards an adjacent basin, the attendant outflow is expected to regulate the lake "dead" $\Sigma \mathrm{CO}_{2}$ until it reaches a steady state. In such a case, the HWE and the associated reservoir age should remain rather low and constant.

In addition to changes in the water budget explaining long reservoir age trends in lakes, changes in "dead" $\Sigma \mathrm{CO}_{2}$ total input linked to changes the riverine runoff and riverine "dead" $\Sigma \mathrm{CO}_{2}$ are also expected to change the lake HWE and the reservoir age. Changes in runoff depend upon precipitation changes, while riverine "dead" $\Sigma \mathrm{CO}_{2}$ mainly depends upon changes in the chemical weathering intensity within the lake catchment.

\subsubsection{From an open to an enclosed Black Sea "Lake"}

Black Sea "Lake" reservoir ages show a drastic change between HE2 and HE1, with a continuous increase reaching values 10 to 15 times higher than the constant reservoir age that occurred prior to HE2 (Fig. 9 and Table 1). Prior to HE2, constant reservoir ages are 
likely due to a persisting positive water budget, and, thus, to an outflow of the Black Sea "Lake" into the Marmara Sea; while low values suggest a low river "dead" $\Sigma \mathrm{CO}_{2}$ content, a result of the glacial predominance of physical rock weathering. Between HE2 and HE1, the increasing trend in reservoir age could either be due to an increasing input of "dead" $\Sigma \mathrm{CO}_{2}$ by rivers or to an accumulation of "dead" $\Sigma \mathrm{CO}_{2}$ in the lake due to a water budget shift toward an evaporative state, leading to an outflow interruption. The regional hydrologic context, colder and dryer conditions during the Last Glacial Maximum (LGM) linked with a weakened continental hydrologic cycle (Allen et al., 1999; Combourieu-Nebout et al., 2002; Fleitmann et al., 2009; Tzedakis et al., 2002), supports the second hypothesis. Seismic observations indicate a major glacial Black Sea "Lake" lowstand with a water level located at approximately $-120 \mathrm{~m}$ (e.g. Aksu et al., 2002b; Kaplin and Selivanov, 2004; Lericolais et al., 2009; Popescu et al., 2004; Ryan et al., 1997), supporting a glacial evaporative water budget. However, the age of the glacial lowstand remains uncertain (Popescu et al., 2004). Our results strongly suggest a Black Sea "Lake" evaporative water budget from HE2 until the LGM, implying a lake level decrease since HE2, with a lowstand reached sometime during the LGM.

\subsubsection{From an enclosed to an open Black Sea "Lake"}

During HE1, the Black Sea "Lake" reservoir age quickly decreased from high values to $250 \mathrm{yr}$ (Fig. 9). By taking into account that the Black Sea "Lake" was likely strictly isolated (without outflow) due to an evaporative water budget during the full glacial, the only way to decrease reservoir ages is the dilution of lake "dead" $\Sigma \mathrm{CO}_{2}$ and an attendant increase in lake $\Sigma^{14} \mathrm{CO}_{2}$, in response to a water budget shift from an evaporative to a positive state. The drastic reservoir age decrease, also previously estimated by Kwiecien et al. (2008), occurred concomitantly with deposition of Red Layers (Fig. 8), which represent the sedimentary signature of short-lived ( $200 \mathrm{yr}$ in duration; this study) melt water pulses (Bahr et al., 2006; Kwiecien et al., 2009; Major et al., 2006) that likely brought large amounts of water to the Black Sea "Lake". After the last melt water pulses (the last peak in XRF-Ti/Ca in Fig. 9; RL1 in Fig. 2), the reservoir age was continuously decreasing, suggesting that the Black Sea "Lake" water budget remained positive until at least the onset of the BøllingAllerød. Indeed, any reestablishment of evaporative conditions would have inevitably increased the reservoir age through the concentration of "dead" $\Sigma \mathrm{CO}_{2}$. Such a long period ( $\left.3000 \mathrm{yr}\right)$ of a persisting positive water budget would have led the Black Sea "Lake" to reach its outlet level ( 25 mbsl; Soulet et al., 2011). As a result, the Black Sea "Lake" would have outflowed into the Marmara Sea.

In the Marmara Sea, ostracod $\delta^{18} \mathrm{O}$, reflecting bottom water $\delta^{18} \mathrm{O}$, decreased by $\sim 1 \%$ o (Vidal et al., 2010) concomitant with a similar decrease in ostracod $\delta^{18} \mathrm{O}$ as recorded in the Black Sea "Lake" during melt water pulses (Bahr et al., 2006, 2008; Kwiecien et al., 2009). Vidal et al. (2010) suggested that, during melt water pulses, outflowing Black Sea "Lake" waters isotopically imprinted Marmara Sea waters. Another peculiar geochemical record also supports an outflowing Black Sea "Lake". During melt water pulses, water ${ }^{87} \mathrm{Sr} /{ }^{86} \mathrm{Sr}$ drastically increased as a result of a change in water sources (Major et al., 2006). Between two melt water pulse episodes and following the last pulse until Bølling-Allerød onset, water ${ }^{87} \mathrm{Sr} /{ }^{86} \mathrm{Sr}$ dropped, suggesting that an outflow of the Black Sea "Lake" into the Marmara Sea flushed the ${ }^{87}$ Sr-rich lake water (Bahr et al., 2008).

\subsubsection{Parameters other than river-induced HWE in reservoir age changes}

A careful examination of our reservoir age record strongly suggests that, on short time scales, parameters others than those linked with the water budget of the Black Sea "Lake" could be of importance for the $\mathrm{\Sigma} \mathrm{CO}_{2}$ budget.
At $14.8 \mathrm{kyr}$ BP (Bølling-Allerød onset), the reservoir age instantaneously increased by $\sim 500 \mathrm{yr}$, reaching values close to $750 \mathrm{yr}$ (Fig. 9), The HWE, which requires longer time scales, cannot explain this increase. An alternative explanation could be the sudden release of "dead" $\Sigma \mathrm{CO}_{2}$ from the methanotrophic utilization of "dead" $\mathrm{CH}_{4}$, triggered by a sudden clathrate dissociation within the sediment. At the onset of the Bølling-Allerød, a sudden increase in surface temperature may have triggered clathrate dissociation (Figs. 2 and 3). Similar clathrate dissociation events associated with deglacial warming that were recently described within the Marmara Sea (Ménot and Bard, 2010) and within Lake Baïkal (Prokopenko and Williams, 2004) could support this hypothesis. However, further work is needed to strengthen this hypothesis for the Black Sea "Lake".

Following this reservoir age increase, the surface water reservoir age remained stable at $\sim 280 \mathrm{yr}$, suggesting low HWE and a constant outflow. From the Bølling-Allerød to the last reconnection, the water budget is highly debated. A high water level (e.g. Aksu et al., 2002a; Hiscott et al., 2007) would have flushed $\Sigma \mathrm{CO}_{2}$, limiting HWE exactly as for the period prior to HE2. On the other hand, a low water level (e.g. Bahr et al., 2008; Lericolais et al., 2007; Major et al., 2006; Ryan et al., 2003) would have increased HWE by "dead" $\Sigma \mathrm{CO}_{2}$ accumulation, therefore, increasing the reservoir age. Productivity occurring during this time period (Bahr et al., 2005, 2006, 2008; Major et al., 2002, 2006) may have allowed a counteraction in the expected reservoir age increase by removing $\mathrm{\Sigma CO}_{2}$ through authigenic calcite precipitation (Kwiecien et al., 2008). However, the quantitative impact of productivity on reservoir age changes still remains to be deciphered. Further work involving transient state box models is required in order to resolve the issue.

\subsection{Black Sea "Lake" stratification phases}

Water stratification, by reducing water exchanges, increases the reservoir age for both shallow and deeper water bodies (e.g. Bard, 1988; Siani et al., 2001; Stuiver et al., 1986). The result, in terms of the reservoir age, is that deep waters exhibit higher reservoir ages than shallower waters. Such decoupling represents a geochemical signature for water stratification.

Based upon the decoupling of ostracod- $\delta{ }^{18} \mathrm{O}$, as well as $\mathrm{Mg} / \mathrm{Ca}$ and $\mathrm{Sr} / \mathrm{Ca}$ profiles from cores retrieved at different water depths (Bahr et al., 2006, 2008), a unique phase of evaporative-driven stratification was previously reported (Bahr et al., 2006, 2008). Our results indicate two stratification periods - one since the Bølling-Allerød until the reconnection in agreement with Bahr et al. (2006, 2008), and another during the full glacial (HE2 and LGM) (Fig. 9).

During the full glacial, shallow and deep reservoir ages began to decouple near the onset of HE2 (Fig. 9). We suggest that the reservoir age increase was due to an increasing HWE due to an evaporative water budget. Therefore, observed decoupling implies higher "dead" $\Sigma \mathrm{CO}_{2}$ content (i.e. higher alkaline salinity) in deep rather than in shallower waters. As a result, full glacial stratification may have been due to an alkaline salinity gradient within the water column. In many cases, salinity's (total salt) contribution to the water density is greater than the thermal contribution (Boehrer and Schultze, 2008) and could have prevented surface water temperatures from reaching the maximum in water density, and, therefore, mixing into the entire water column. As a result, an increased full glacial Black Sea "Lake" salinity could likely be responsible for the observed stratification. By measuring the pore water chloride content and by using a diffusionadvection model, Soulet et al. (2010) suggested that the glacial Black Sea "Lake" was a fresh water lake. If reservoir age data prior to HE2 and following HE1 seem to confirm this conclusion, they also point out that Black Sea "Lake" salinity has progressively increased from HE2 through the LGM. This discrepancy likely results from the fact that during some time windows the chloride content may have not been fully representative for the Black Sea "Lake" total salt pool. 


\section{Conclusions}

A new high-resolution geochemical dataset from core MD04-2790 allowed us to build a reliable calendar age chronology for the Late Quaternary history of the Black Sea "Lake". Calendar ages and new radiocarbon ages were combined in order to reconstruct a highresolution reservoir age record for the Black Sea "Lake" from 32 kyr $\mathrm{BP}$ to the last reconnection with the Mediterranean Sea.

Between 32 and $8 \mathrm{kyr} \mathrm{BP}$, the reservoir age varied markedly between values, ranging from $\sim 200$ to $\sim 2000 \mathrm{yr}$. Large reservoir age changes were always associated with climate shifts for the last glacial to deglacial period, demonstrating the extreme sensitivity of the Black Sea "Lake" to climate change. In general, changes in reservoir ages were mainly driven by changes in the Hard Water Effect intensity, with the Hard Water Effect itself controlled by the Black Sea "Lake" water budget. By roughly constraining the hydrologic balance, the results presented here provide new evidence for dating the phases of Black Sea "Lake" outflow or lake level drawdown.

In order to reconstruct and compare reservoir age evolution through different depths, we also used previously published radiocarbon ages from cores retrieved at depths deeper than core MD042790 . Here we have defined a previously undocumented stratification phase that occurred during the full glacial (HE2 through LGM). The full glacial stratification was likely due to a temporary vertical alkaline salinity gradient that was established when Black Sea "Lake" level was low enough to prevent water export into the Marmara Sea, allowing the accumulation of salts within the basin.

The reservoir age reconstruction presented here provides evidence for better understanding the hydrologic response of the Black Sea "Lake" since the Last Glacial. The results also provide an example that indicates that the reservoir ages of lakes and inland seas are a powerful tool for investigating and understanding hydrologic responses to climate change in these areas. A coupled transient-state box model that captures water, dissolved inorganic carbon, and radiocarbon budgets would be of great interest for quantitatively ascertaining lake hydrologic changes.

\section{Acknowledgments}

Our work is a contribution to the ASSEMBLAGE project funded by the European Commission (EVK3-CT-2002-00090). We acknowledge G. Bayon and J. Etoubleau (Ifremer, Brest) for technical assistance during XRF data acquisition. We also thank S. Toucanne for fruitful discussions. Two anonymous reviewers provided constructive reviews for which we are grateful. We also thank the LMC14-ARTEMIS for ${ }^{14} \mathrm{C}$ by SMA in the frame of the National Service to INSU. We are grateful to CNRS, Ifremer, and the Collège de France for providing salary support to G. Soulet. Paleoclimate work at CEREGE is supported by grants from the Gary Comer Foundation for Science and Education, the European Community (Project Past4Future), and the Collège de France.

\section{References}

Aksu, A., Hiscott, R.N., Mudie, P., Rochon, A., Kaminski, M.A., Abrajano, T., Yasar, D. 2002a. Persistent holocene outflow from the Black Sea to the eastern Mediterranean contradicts Noah's flood hypothesis. GSA Today 12, 4-10.

Aksu, A.E., Hiscott, R.N., Yasar, D., Isler, F.I., Marsh, S., 2002b. Seismic stratigraphy of Late Quaternary deposits from the southwestern Black Sea shelf: evidence for noncatastrophic variations in sea-level during the last 10,000 yr. Mar. Geol. 190, 61-94.

Allen, J.R.M., Brandt, U., Brauer, A., Hubberten, H.-W., Huntley, B., Keller, J., Kraml, M., Mackensen, A., Mingram, J., Negendank, J.F.W., Nowaczyk, N.R., Oberhänsli, H., Watts, W.A., Wulf, S., Zolitschka, B., 1999. Rapid environmental changes in southern Europe during the last glacial period. Nature 400, 740-743.

Andrée, M., Oeschger, H., Broecker, W., Beavan, N., Klas, M., Mix, A., Bonani, G., Hofmann, H.J., Suter, M., Woelfli, W., Peng, T.H., 1986a. Limits on the ventilation rate for the deep ocean over the last 12000 years. Clim. Dyn. 1, 53-62.

Andrée, M., Oeschger, H., Siegenthaler, U., Riesen, T., Moell, M., 1986b. ${ }^{14} \mathrm{C}$ dating of plant macrofossils in lake sediment. Radiocarbon 28, 411-416.
Arnold, J.R., Anderson, E.C., 1957. The distribution of radiocarbon in nature. Tellus 9, $28-32$.

Ascough, P.L., Cook, G.T., Church, M.J., Dunbar, E., Einarsson, Á., McGovern, T.H., Dugmore, A.J., Perdikaris, S., Hastie, H., Friðriksson, A., Gestsdóttir, H., 2010. Temporal and spatial variations in freshwater ${ }^{14} \mathrm{C}$ reservoir effects: Lake Mývatn, Northern Iceland. Radiocarbon 52, 1098-1112.

Bahr, A., Lamy, F., Arz, H., Kuhlmann, H., Wefer, G., 2005. Late glacial to Holocene climate and sedimentation history in the NW Black Sea. Mar. Geol. 214, 309-322.

Bahr, A., Arz, H.W., Lamy, F., Wefer, G., 2006. Late glacial to Holocene paleoenvironmental evolution of the Black Sea, reconstructed with stable oxygen isotope records obtained on ostracod shells. Earth Planet. Sci. Lett. 241, 863-875.

Bahr, A., Lamy, F., Arz, H.W., Major, C., Kwiecien, O., Wefer, G., 2008. Abrupt changes of temperature and water chemistry in the late Pleistocene and early Holocene Black Sea. Geochem. Geophys. Geosyst. 9, Q01004. doi:10.1029/2007gc001683.

Bard, E., 1988. Correction of accelerator mass spectrometry ${ }^{14} \mathrm{C}$ ages measured in planktonic foraminifera: paleoceanographic implications. Paleoceanography 3, 635-645.

Bard, E., Arnold, M., Mangerud, J., Paterne, M., Labeyrie, L., Duprat, J., Mélières, M.-A., Sønstegaard, E., Duplessy, J.-C., 1994. The North Atlantic atmosphere-sea surface ${ }^{14} \mathrm{C}$ gradient during the Younger Dryas climatic event. Earth Planet. Sci. Lett. 126, 275-287.

Bard, E., Rostek, F., Ménot-Combes, G., 2004. Radiocarbon calibration beyond 20,000 ${ }^{14} \mathrm{C}$ yr B.P. by means of planktonic foraminifera of the Iberian Margin. Quat. Res. 61, 204-214.

Boehrer, B., Schultze, M., 2008. Stratification of lakes. Rev. Geophys. 46, RG2005. doi:10.1029/2006rg000210.

Bolton, A.J., Maltman, A.J., Clennell, M.B., 1998. The importance of overpressure timing and permeability evolution in fine-grained sediments undergoing shear. J. Struct. Geol. 20, 1013-1022.

Bondevik, S., Mangerud, J., Birks, H.H., Gulliksen, S., Reimer, P., 2006. Changes in North Atlantic radiocarbon reservoir ages during the Allerod and Younger Dryas. Science 312, 1514-1517.

Broecker, W.S., Olson, E.A., 1961. Lamont radiocarbon measurements VIII. Radiocarbon 3, 176-204.

Buck, C.E., Cavanagh, W.G., Litton, C.D., 1996. The Bayesian Approach to Interpreting Archaeological Data. Wiley, Chichester.

Combourieu-Nebout, N., Turon, J.L., Zahn, R., Capotondi, L., Londeix, L., Pahnke, K., 2002. Enhanced aridity and atmospheric high-pressure stability over the western Mediterranean during the North Atlantic cold events of the past 50 k.y. Geology 30, 863-866

Craig, H., 1957. The natural distribution of radiocarbon and the exchange time of carbon dioxide between atmosphere and sea. Tellus 9, 1-17.

Denton, G.H., Alley, R.B., Comer, G.C., Broecker, W.S., 2005. The role of seasonality in abrupt climate change. Quat. Sci. Rev. 24, 1159-1182.

Eynaud, F., Zaragosi, S., Scourse, J., Mojtahid, M., Bourillet, J.F., Hall, I.R., Penaud, A., Locascio, M., Reijonen, A., 2007. Deglacial laminated facies on the NW European continental margin: the hydrographic significance of British-Irish Ice Sheet deglaciation and Fleuve Manche paleoriver discharges. Geochem. Geophys. Geosyst. 8. doi:10.1029/2006GC00.

Fedorov, P.V., 1971. Postglacial transgression of the Black Sea. Int. Geol. Rev. 14, $160-164$.

Fleitmann, D., Cheng, H., Badertscher, S., Edwards, R.L., Mudelsee, M., Göktürk, O.M., Fankhauser, A., Pickering, R., Raible, C.C., Matter, A., Kramers, J., Tüysüz, O., 2009. Timing and climatic impact of Greenland interstadials recorded in stalagmites from northern Turkey. Geophys. Res. Lett. 36, L19707. doi:10.1029/2009gl040050.

Giosan, L., 2007. In: Yanko-Hombach, V., Gilbert, A.S., Panin, N., Dolukhanov, P.M. (Eds.), The Black Sea Flood Question: Changes in Coastline, Climate and Human Settlement. : Quaternary Science Reviews, 26. Springer, Berlin. ISBN: 978-14020-4774-9, pp. 1897-1900. 971pp., 246 illus.

Giosan, L., Donnelly, J.P., Constantinescu, S., Filip, F., Ovejanu, I., Vespremeanu-Stroe, A., Vespremeanu, E., Duller, G.A.T., 2006. Young Danube delta documents stable Black Sea level since the middle Holocene: morphodynamic, paleogeographic, and archaeological implications. Geology 34, 757-760.

Hiscott, R.N., Aksu, A.E., Mudie, P.J., Marret, F., Abrajano, T., Kaminski, M.A., Evans, J., Cakiroglu, A.I., Yasar, D., 2007. A gradual drowning of the southwestern Black Sea shelf: evidence for a progressive rather than abrupt Holocene reconnection with the eastern Mediterranean Sea through the Marmara Sea Gateway. Quat. Int. 167-168, 19-34.

Hughen, K.A., Eglinton, T.I., Xu, L., Makou, M., 2004. Abrupt tropical vegetation response to rapid climate changes. Science 304, 1955-1959.

Hughen, K., Southon, J., Lehman, S., Bertrand, C., Turnbull, J., 2006. Marine-derived ${ }^{14} \mathrm{C}$ calibration and activity record for the past 50,000 years updated from the Cariaco Basin. Quat. Sci. Rev. 25, 3216-3227.

Jansen, J.H.F., Van der Gaast, S.J., Koster, B., Vaars, A.J., 1998. CORTEX, a shipboard XRFscanner for element analyses in split sediment cores. Mar. Geol. 151, 143-153.

Kaplin, P.A., Selivanov, A.O., 2004. Lateglacial and Holocene sea level changes in semienclosed seas of North Eurasia: examples from the contrasting Black and White Seas. Palaeogeogr. Palaeoclimatol. Palaeoecol. 209, 19-36.

Kwiecien, O., Arz, H., Lamy, F., Wulf, S., Bahr, A., Röhl, U., Haug, G.H., 2008. Estimated reservoir ages of the Black Sea since the last glacial. Radiocarbon 50, 99-118.

Kwiecien, O., Arz, H.W., Lamy, F., Plessen, B., Bahr, A., Haug, G.H., 2009. North Atlantic control on precipitation pattern in the eastern Mediterranean/Black Sea region during the last glacial. Quat. Res. 71, 375-384.

Leng, M.J., Marshall, J.D., 2004. Palaeoclimate interpretation of stable isotope data from lake sediment archives. Quat. Sci. Rev. 23, 811-831.

Lericolais, G., Popescu, I., Guichard, F., Popescu, S.M., 2007. A Black Sea lowstand at $8500 \mathrm{yr}$ B.P. indicated by a relict coastal dune system at a depth of $90 \mathrm{~m}$ below sea level. Geol. Soc. Am. Bull. Spec. Pap. 426, 171-188. 
Lericolais, G., Bulois, C., Gillet, H., Guichard, F., 2009. High frequency sea level fluctuations recorded in the Black Sea since the LGM. Global Planet. Change 66, 65-75.

Litt, T., Brauer, A., Goslar, T., Merkt, J., Balaga, K., Müller, H., Ralska-Jasiewiczowa, M., Stebich, M., Negendank, J.F.W., 2001. Correlation and synchronisation of Lateglacial continental sequences in northern central Europe based on annually laminated lacustrine sediments. Quat. Sci. Rev. 20, 1233-1249.

Major, C., Ryan, W., Lericolais, G., Hajdas, I., 2002. Constraints on Black Sea outflow to the Sea of Marmara during the last glacial-interglacial transition. Mar. Geol. 190, 19-34.

Major, C.O., Goldstein, S.L., Ryan, W.B.F., Lericolais, G., Piotrowski, A.M., Hajdas, I., 2006. The co-evolution of Black Sea level and composition through the last deglaciation and its paleoclimatic significance. Quat. Sci. Rev. 25, 2031-2047.

Mangerud, J., 1972. Radiocarbon dating of marine shells, including a discussion of apparent age of recent shells from Norway. Boreas 1, 143-172.

Ménot, G., Bard, E., 2010. Geochemical evidence for a large methane release during the last deglaciation from Marmara Sea sediments. Geochim. Cosmochim. Acta 74, 1537-1550.

Ménot, G., Soulet, G., Bard, E., in preparation. First quantitative reconstruction of millennial-scale temperature variations in Central Europe.

Mook, W.G., van der Plicht, J., 1999. Reporting ${ }^{14} \mathrm{C}$ activities and concentrations. Radiocarbon 41, 227-239.

NGRIP members, 2004. High-resolution record of Northern Hemisphere climate extending into the last interglacial period. Nature 431, 147-151.

Pailler, D., Bard, E., 2002. High frequency palaeoceanographic changes during the past $140,000 \mathrm{yr}$ recorded by the organic matter in sediments of the Iberian Margin. Palaeogeogr. Palaeoclimatol. Palaeoecol. 181, 431-452.

Pirazzoli, P.A., 1991. World Atlas of Holocene Sea-Level Changes. Elsevier, Amsterdam.

Popescu, I., Lericolais, G., Panin, N., Normand, A., Dinu, C., Le Drezen, E., 2004. The Danube submarine canyon (Black Sea): morphology and sedimentary processes. Mar. Geol. 206, 249-265.

Prokopenko, A.A., Williams, D.F., 2004. Deglacial methane emission signals in the carbon isotopic record of Lake Baikal. Earth Planet. Sci. Lett. 218, 135-147.

Reimer, P.J., Baillie, M.G.L., Bard, E., Bayliss, A., Beck, J.W., Blackwell, P.G., Bronk Ramsey, C., Buck, C.E., Burr, G.S., Edwards, R.L., Friedrich, M., Grootes, P.M., Guilderson, T.P., Hajdas, I., Heaton, T.J., Hogg, A.G., Hughen, K.A., Kaiser, K.F., Kromer, B., McCormac, G., Manning, S., Reimer, R.W., Richards, D.A., Southon, J.R., Talamo, S., Turney, C.S.M., van der Plicht, J. Weyhenmeyer, C.E., 2009. IntCal09 and Marine09 Radiocarbon Age Calibration Curves, $0-50,000$ years cal BP. Radiocarbon $51,1111-1150$.

Ross, D.A., Degens, E.T., 1974. Recent sediments of Black Sea. In: Degens, E.T., Ross, D.A. (Eds.), The Black Sea: Geology, Chemistry, and Biology. American Association of Petroleum Geologists, Tulsa, pp. 183-199.

Ross, D.A., Degens, E.T., MacIlvaine, J., 1970. Black Sea: Recent Sedimentary History. Science 170, 163-165.

Ruth, U., Bigler, M., Röthlisberger, R., Siggaard-Andersen, M.-L., Kipfstuhl, S., GotoAzuma, K., Hansson, M.E., Johnsen, S.J., Lu, H., Steffensen, J.P., 2007. Ice core evidence for a very tight link between North Atlantic and east Asian glacial climate. Geophys. Res. Lett. 34, L03706. doi:10.1029/2006gl027876.

Ryan, W.B.F., 2007. Status of the Black Sea flood hypothesis. In: Yanko-Hombach, V., Gilbert, A.S., Panin, N. (Eds.), The Black Sea Flood Question: Changes in Coastline, Climate and Human Settlement. Springer, New York, pp. 63-88.

Ryan, W.B.F., Pitman, W.C., 1998. Noah's Flood: The New Scientific Discoveries about the Event that Changes History. Simon \& Schuster, New-York, 319p.

Ryan, W.B.F., Pitman, W.C., Major, C.O., Shimkus, K., Moskalenko, V., Jones, G.A., Dimitrov, P., Gorür, N., Sakinç, M., Yüce, H., 1997. An abrupt drowning of the Black Sea shelf. Mar. Geol. 138, 119-126.

Ryan, W.B.F., Major, C.O., Lericolais, G., Goldstein, S.L., 2003. Catastrophic flooding of the Black Sea. Annu. Rev. Earth Planet. Sci. 31, 525-554.

Schouten, S., Hopmans, E.C., Schefuß, E., Sinninghe Damsté, J.S., 2002. Distributional variations in marine crenarchaeotal membrane lipids: a new tool for reconstructing ancient sea water temperatures? Earth Planet. Sci. Lett. 204, 265-274.

Schouten, S., Hopmans, E.C., van der Meer, J., Mets, A., Bard, E., Bianchi, T.S., Diefendorf, A. Escala, M., Freeman, K.H., Furukawa, Y., Huguet, C., Ingalls, A., Ménot-Combes, G., Nederbragt, A.J., Oba, M., Pearson, A., Pearson, E.J., Rosell-Melé, A., Schaeffer, P., Shah, S.R., Shanahan, T.M., Smith, R.W., Smittenberg, R., Talbot, H.M., Uchida, M., Van Mooy, B.A.S., Yamamoto, M., Zhang, Z., Sinninghe Damsté, J.S., 2009. An interlaboratory study of TEX86 and BIT analysis using high-performance liquid chromatography/mass spectrometry. Geochem. Geophys. Geosyst. 10, Q03012. doi:10.1029/2008GC002221.
Schrader, H.-J., 1979. Quaternary paleoclimatology of the Black Sea basin. Sediment. Geol. 23, 165-180.

Severinghaus, J.P., Brook, E.J., 1999. Abrupt climate change at the end of the last glacia period inferred from trapped air in polar ice. Science 286, 930-934.

Severinghaus, J.P., Sowers, T., Brook, E.J., Alley, R.B., Bender, M.L., 1998. Timing of abrupt climate change at the end of the Younger Dryas interval from thermally fractionated gases in polar ice. Nature 391, 141-146.

Siani, G., Paterne, M., Michel, E., Sulpizio, R., Sbrana, A., Arnold, M., Haddad, G., 2001 Mediterranean Sea surface radiocarbon reservoir age changes since the Last Glacial Maximum. Science 294, 1917-1920.

Siegenthaler, U., Heimann, M., Oeschger, H., $1980 .{ }^{14} \mathrm{C}$ variations caused by changes in the global carbon cycle. Radiocarbon 22, 177-191.

Soulet, G., Delaygue, G., Vallet-Coulomb, C., Böttcher, M.E., Sonzogni, C., Lericolais, G. Bard, E., 2010. Glacial hydrologic conditions in the Black Sea reconstructed using geochemical pore water profiles. Earth Planet. Sci. Lett. 296, 57-66.

Soulet, G., Ménot, G., Lericolais, G., Bard, E., 2011. A revised calendar age for the last reconnection of the Black Sea to the global ocean. Quat. Sci. Rev. 30, 1019-1026.

Steffensen, J.P., Andersen, K.K., Bigler, M., Clausen, H.B., Dahl-Jensen, D., Fischer, H., Goto-Azuma, K., Hansson, M., Johnsen, S.J., Jouzel, J., Masson-Delmotte, V., Popp, T., Rasmussen, S.O., Rothlisberger, R., Ruth, U., Stauffer, B., Siggaard-Andersen, M.-L. Sveinbjornsdottir, A.E., Svensson, A., White, J.W.C., 2008. High-resolution Greenland ice core data show abrupt climate change happens in few years. Science 321, 680-684.

Stein, M., Migowski, C., Bookman, R., Lazar, B., 2004. Temporal changes in radiocarbon reservoir age in the Dead Sea Lake Lisan system. Radiocarbon 46, 649-655.

Stoffers, P., Degens, E.T., Trimonis, E.S., 1978. Stratigraphy and suggested ages of Black Sea sediments cored during Leg 42B. In: Ross, D.A., Neprochnov, Y.P., et al. (Eds.) Initial Reports of the Deep Sea Drilling Project. U.S Government Printing Office, Washington, pp. 483-488.

Stuiver, M., Polach, H.A., 1977. Discussion reporting of ${ }^{14} \mathrm{C}$ data. Radiocarbon 19 355-363.

Stuiver, M., Pearson, G.W., Braziunas, T.F., 1986. Radiocarbon age calibration of marine samples back to 9000 cal. yr BP. Radiocarbon 28, 980-1021.

Suess, E., Revelle, R., 1957. Carbon dioxide exchange between the atmosphere and ocean and the question of an increase of atmospheric $\mathrm{CO}_{2}$ during the past decades. Tellus 9, 18-27.

Toucanne, S., Zaragosi, S., Bourillet, J.F., Cremer, M., Eynaud, F., Van Vliet-Lanoë, B., Penaud, A., Fontanier, C., Turon, J.L., Cortijo, E., Gibbard, P.L., 2009. Timing of massive 'Fleuve Manche' discharges over the last $350 \mathrm{kyr}$ : insights into the European ice-sheet oscillations and the European drainage network from MIS 10 to 2. Quat. Sci. Rev. 28, 1238-1256.

Tzedakis, P.C., Lawson, I.T., Frogley, M.R., Hewitt, G.M., Preece, R.C., 2002. Buffered tree population changes in a Quaternary refugium: evolutionary implications. Science 297, 2044-2047.

Vidal, L., Ménot, G., Joly, C., Bruneton, H., Rostek, F., Çagatay, M.N., Major, C., Bard, E., 2010. Hydrology in the Sea of Marmara during the last $23 \mathrm{ka}$ : implications for timing of Black Sea connections and sapropel deposition. Paleoceanography 25 PA1205. doi:10.1029/2009pa001735.

Wang, Y.J., Cheng, H., Edwards, R.L., An, Z.S., Wu, J.Y., Shen, C.-C., Dorale, J.A., 2001. A high-resolution absolute-dated late Pleistocene monsoon record from Hulu Cave, China. Science 294, 2345-2348.

Wolff, E.W., Chappellaz, J., Blunier, T., Rasmussen, S.O., Svensson, A., 2010. Millennialscale variability during the last glacial: the ice core record. Quat. Sci. Rev. 29, 2828-2838.

Yanko-Hombach, V., Gilbert, A.S., Panin, A.V., Dolukhanov, P.M. (Eds.), 2007. The Black Sea Flood Question: Changes in Coastline, Climate, and Human Settlement Springer, New York.

Zaragosi, S., Eynaud, F., Pujol, C., Auffret, G.A., Turon, J.L., Garlan, T., 2001. Initiation of the European deglaciation as recorded in the northwestern Bay of Biscay slope environments (Meriadzek Terrace and Trevelyan Escarpment): a multi-proxy approach. Earth Planet. Sci. Lett. 188, 493-507.

Zaragosi, S., Bourillet, J.-F., Eynaud, F., Toucanne, S., Denhard, B., Van Toer, A., Lanfumey, V., 2006. The impact of the last European deglaciation on the deep-sea turbidite systems of the Celtic-Armorican margin (Bay of Biscay). Geo-Mar. Lett. 26, 317-329.

Zhou, A.-f., F.-h., Chen, Z.-l., Wang, Yang, M.-l., Qiang, M.-r., Zhang, J.-w., 2009. Temporal change of radiocarbon reservoir effect in Sugan Lake, northwest China during the Late Holocene. Radiocarbon 51, 529-535. 